\title{
Towards Higher Quality of Recycled Plastics: Limitations from the Material's Perspective
}

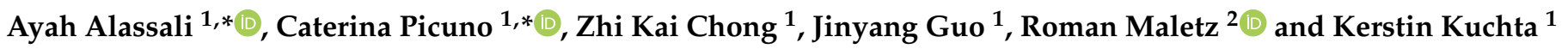 \\ 1 Institute of Environmental Technology and Energy Economics, Sustainable Resource and Waste Management, \\ Hamburg University of Technology, Blohmstrasse 15, 21079 Hamburg, Germany; kai.chong@tuhh.de (Z.K.C.); \\ jy.guo@tuhh.de (J.G.); kuchta@tuhh.de (K.K.) \\ 2 Institute of Waste Management and Circular Economy, Technische Universität Dresden, \\ 01796 Pirna, Germany; roman.maletz@tu-dresden.de \\ * Correspondence: ayah.alassali@tuhh.de (A.A.); caterina.picuno@tuhh.de (C.P.); \\ Tel.: +49-40-42878-2438 (A.A.); +49-40-42878-4650 (C.P.)
}

check for updates

Citation: Alassali, A.; Picuno, C.; Chong, Z.K.; Guo, J.; Maletz, R.; Kuchta, K. Towards Higher Quality of Recycled Plastics: Limitations from the Material's Perspective. Sustainability 2021, 13, 13266. https://doi.org/10.3390/su132313266

\section{Academic Editors: John}

N. Hahladakis, Eleni Iacovidou and Eggo Ulphard Thoden van Velzen

Received: 3 November 2021

Accepted: 25 November 2021

Published: 30 November 2021

Publisher's Note: MDPI stays neutral with regard to jurisdictional claims in published maps and institutional affiliations.

Copyright: (c) 2021 by the authors. Licensee MDPI, Basel, Switzerland. This article is an open access article distributed under the terms and conditions of the Creative Commons Attribution (CC BY) license (https:// creativecommons.org/licenses/by/ $4.0 /)$.

\begin{abstract}
The increasing consumption of plastics and plastic products results in correspondingly substantial volumes of waste, which poses considerable environmental burdens. With the ongoing environmental actions, the application of circular economy on this waste stream is becoming inevitable. In this paper, the topics of plastics recycling, circular economy on plastics, and challenges to plastic waste recycling are critically reviewed. In the first part of this paper, the development of research on plastic recycling was viewed from 1950 until 2020 using the scientific database Web of Science, and 682 related studies were found and used to assess the changing research priorities along that timeline. The following sections discuss the potentials and requirements to enhance the quality of the produced recycled plastic, in connection with the factors that currently limit it. In conclusion, the quality of recycled plastic is generally determined by the homogeneity of the recovered plastic feed. There are various strategies which could be implemented to overcome the hindrances identified in the paper and to improve the quality of the recycled plastic, such as working on enhanced product designs for minimised waste heterogeneity and controlling the materials' degree of contamination by applying advanced sorting.
\end{abstract}

Keywords: plastic waste; mechanical recycling; recycled material quality; limitations plastic recycling

\section{Introduction}

The expansive consumption of plastics results in correspondingly large volumes of waste. This poses substantial challenges to the available waste management systems [1,2]. In 2018 alone, the global plastic consumption reached $385 \mathrm{Mt}$, with a total generated waste of $250 \mathrm{Mt}$ (i.e., signifying 65\% of all consumed plastics). Of these, $50 \mathrm{Mt}$ were sent for material recycling, $51 \mathrm{Mt}$ were sent for energy recovery, and $72 \mathrm{Mt}$ were disposed of in managed landfills. The rest (i.e., $77 \mathrm{Mt}$ of the plastic waste) has unknown fates [3].

Ending the plastic waste problem is becoming a global priority, pushing stakeholders to take actions to enhance the existing waste management systems and to invest in new ones [4]. Overall, recycling is the preferred option to treat plastics waste. However, when recycling is not the most sustainable option, energy recovery is the alternative [5]. All in all, both options complement each other to exploit the full potential of plastic waste [6]. The global amount of plastic waste incinerated and recycled is still low in comparison to plastic waste landfilling (see Figure 1a). On the other hand, Europe showed improvements in plastic waste treatment; since 2013, the amounts of incinerated plastic waste have exceeded the amounts of landfilled plastic waste. The same trend was experienced for mechanically recycled plastics from 2015 onwards [7] (Figure 1b). For the EU Countries with a landfill ban in place, thermally treated plastic waste still remains the most preferred management route [8]. 


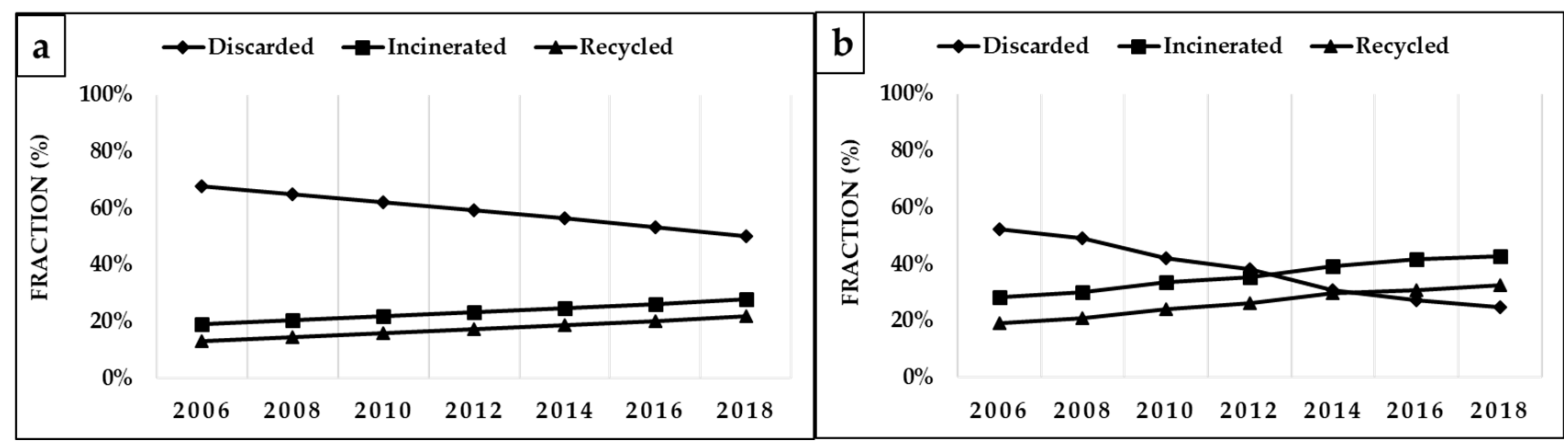

Figure 1. The fractions of plastic wastes discarded, incinerated, and recycled from 2006 until 2018: (a) globally [9] and (b) in Europe [7].

In 2018, Europe achieved 32\% recycling of its own plastic waste [7]. Similarly, Germany reached $33 \%$ of plastic waste recycling ( $1 \%$ chemical, $17 \%$ mechanical recycling inland, and $15 \%$ mechanical recycling abroad) [10]. On the other hand, in the same year in Germany, $66 \%$ of plastic waste was incinerated in comparison to $43 \%$ in Europe.

Plastic mechanical recycling can be performed in closed loops or open loops. Closedloop recycling, also known as primary recycling, is the best to preserve the highest value of the material [11]. Only thermoplastics can be mechanically recycled with the possibility of closed-loop recycling [12]. Nevertheless, the plastic waste stream, particularly when it originates from private consumers [13,14], is significantly heterogeneous and may contain hazardous substances hindering the application of closed-loop recycling $[15,16]$.

There are many additional factors affecting the plastic mechanical recycling practices, including separate collection schemes $[17,18]$, polymer type $[19,20]$, product design, and product category [21]. The different polymer types have different potentials for mechanical recycling. The chemical structure of the polymer and its chemical stability under recycling conditions define its recyclability and the number of recycling cycles it can endure. Additionally, different plastics have different applications and properties [22]. Hence, additives are differently utilised, as required by the material's quality or the product's design. The existence of chemical additives may interfere with the recycling process [15,23]. For instance, plastics containing volatile hazardous additives, such as brominated flame retardants, are not commonly considered for recycling [24]. The product design and product type may hinder recycling through the existence of multi-layer and multi-component materials in one product $[13,25]$. Rigid containers, consisting of a single polymer with minimum amounts of additives and inks, are more efficiently and economically recyclable in comparison to multi-layer and multi-component products [1].

In line with the EU "closed-loop recycling policy", which sets legally binding targets for waste recycling and landfill reduction with specific deadlines [26], and the current regulations demanding for specific recycling quotas $[27,28]$, there is an increased importance to analysing the technical limitations and challenges in mechanically recycling plastic material. These could stem from: (i) how the material is managed at end-of-life stage (collection, sorting, recycling practices); (ii) the functionalities, applications, materials, and optical appearance of a product (in other words, how it is designed); (iii) degradation mechanisms occurring during thermal reprocessing, use, and exposure to external factors (e.g., oxygen, UV radiation). This paper aims at providing an overview of the trends in the available literature about plastics recycling and how different parameters (i.e., product's design, collection and sorting, contaminants, and polymer's degradation) influence the output quality. In this context, this paper critically reviews the limitations to the closed-loop recycling of plastics, to define the current status of the scientific research in this field and propose solutions for an enhanced and extended circular economy application. This review paper is a non-systematic literature review. In this sense, the approach to the literature review is to target some, yet not all, of the published scientific articles and online reports 
on the main topics of plastics recycling, circular economy of plastics, and challenges to plastic waste recycling.

\section{State-of-the-Art in Literature and Trends towards Plastic Recycling}

Literature research using the keywords "plastic recycling" or "plastics recycling" between 1950 and 2020 in the databases of Web of Science resulted in a total of 682 publications, distributed per year of publication as indicated in Figure 2. Of these publications, $70 \%$ were in the form of scientific articles. The publications before 1990 were mostly discussing the possibility and feasibility of plastic recycling [29,30], the progress in plastic recycling, and its advantages [31-39]. Between the years 1990 and 2000, more technical research was observed, discussing the recycling schemes [40-44], properties and material quality analysis [45-47], technology, process, and product enhancement [48-55]. As can be seen in Figure 2, from 2018 onwards, an increasing trend in the number of publications was recorded. A deep analysis indicates that the focus was on topics such as circular economy [25,56-61], as well as the recycling of contaminated plastics (e.g., from e-waste and agricultural packaging) $[15,24,62-72]$.

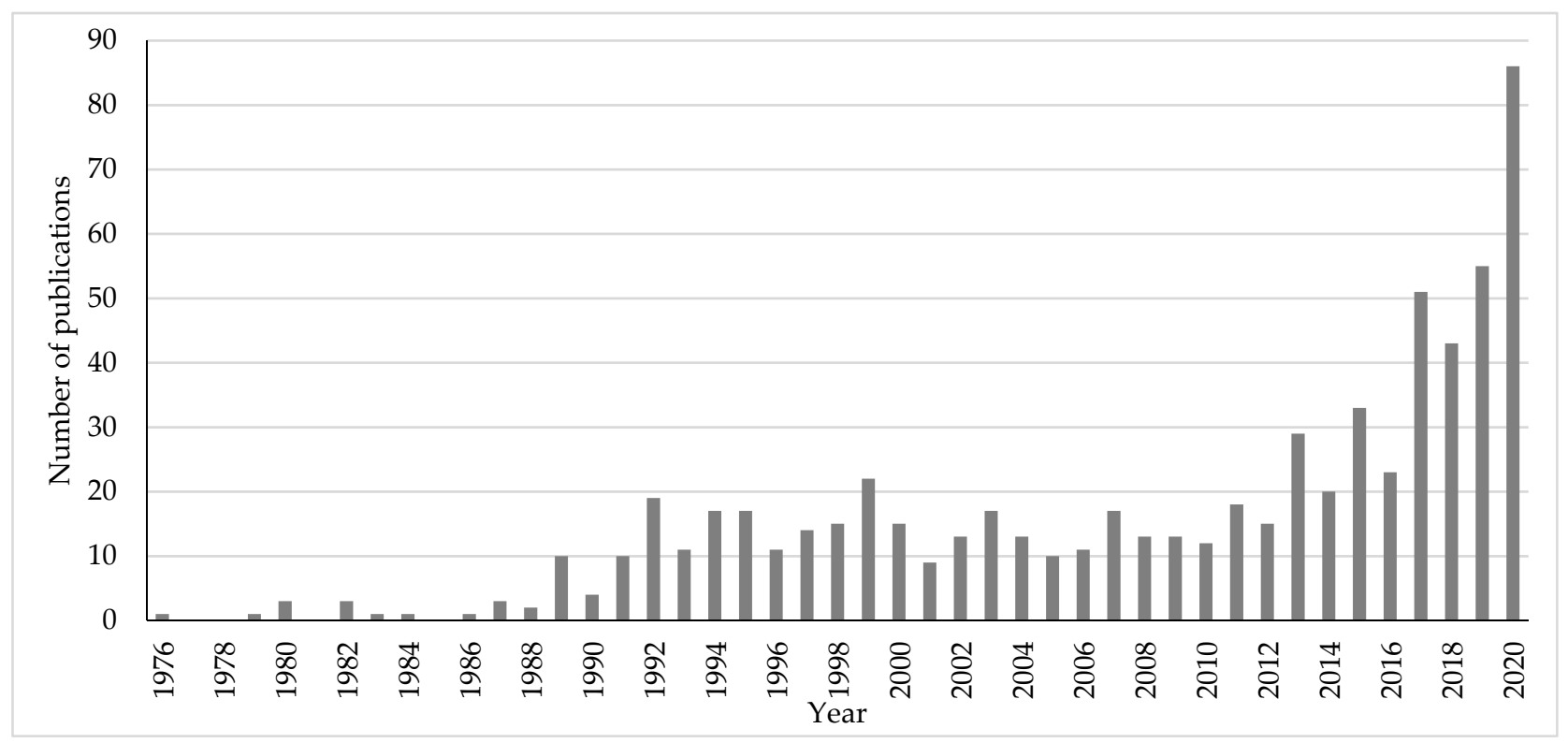

Figure 2. The number of publications per year on the search words "plastic recycling".

Analysing the topics "plastic recycling" and "circular economy" combined during the same lifespan (1950-2020) in the Web of Science Core Collection resulted in a total of 337 publications. A spike in publications associated with both topics combined was observed in 2020, as can be seen in Figure 3. This confirms the trend of discussing plastic recycling in the context of the circular economy. For instance, the topics in 2020 associated with plastic recycling and circular economy mostly discussed the mechanical recycling process and the quality of mechanically recycled plastics [73-78], plastic waste flows and the associated environmental challenges [79-81], and challenges and solutions to the plastic waste recycling [82-87]. In this field, 86 reviewed research combining recycled plastic and additive manufacturing as a path towards a circular economy. The authors found that the technical validation of using recycled plastics in the printing process chain has been the focus of research. They also emphasised the importance of identifying local requirements for the pre-treatment phase, where plastic material from waste needs to be recovered, separated, and cleaned. Additionally, the interconnections between climate change and circular economy are of particular relevance for the current research. 


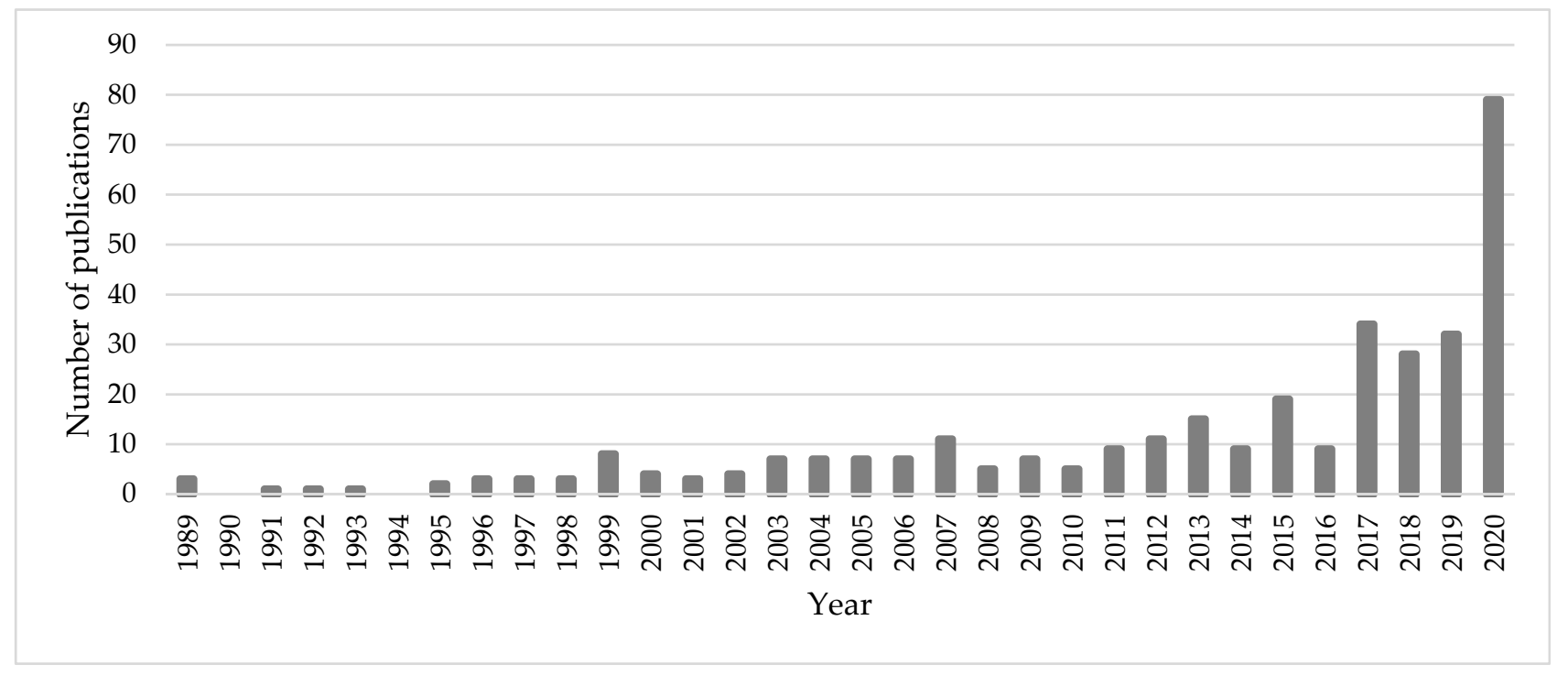

Figure 3. The number of publications per year for "plastic recycling" or "plastics recycling" combined with "circular economy".

For example, Liu et al. [60] studied the relationship between greenhouse gas emissions and the Chinese plastic recycling industry. The link between plastic recycling and greenhouse gas emissions was again examined by Bora et al. [88] through a life cycle approach. Additional topics were the chemical and the feedstock recycling of plastics [89-94].

One of the most discussed topics is related to the challenges and solutions revolving around plastic waste recycling. Technologically, plastics recycling is possible but depends on the quality and cleanness of the recovered material [95]. A comprehensive review on the measures for improving the amount and quality of recycling material can be found in Maletz (2021) [96]. To improve the feasibility of recycling as well as its marketability, the aspects in Figure 4 should be considered.

Improve the
quality of the
recycled materials

Figure 4. High-potential solutions to enhance the feasibility of plastic recycling [95].

The following sections discuss the potentials and requirements to enhance the quality of the produced recycled materials.

\section{The Quality of Recycled Plastic Materials in the Context of a Circular Economy}

Firstly, the definition of the term 'circular economy' as it is proposed by Kirchherr et al. [97] is used as the reference for this paper (pp. 224-225):

'A circular economy describes an economic system that is based on business models which replace the 'end-of-life concept with reducing, alternatively reusing, recycling and recovering materials in production/distribution and consumption processes, thus operating at the micro level (products, companies, consumers), meso level(eco-industrial parks) and macro level (city, region, nation and beyond), with the aim to accomplish sustainable 
development, which implies creating environmental quality, economic prosperity and social equity, to the benefit of current and future generations.'

An integral part of the circular economy for plastic waste is its recycling potential, which generally results from a trade-off between the quantity and the quality of the collected and further reprocessed material. In this sense, many factors are limiting the mechanical recycling of plastic waste [98-101]. Generally, to achieve the plastic waste recycling and recovery goals, sufficient quantities of plastic waste with adequate quality are required. Plastics quality deterioration can significantly limit the application of closedloop recycling. Quality deterioration comes in the form of material degradation $[5,102,103]$ and/or contamination $[15,67,69,104]$.

The degradation of plastic-based products typically takes place during plastic's (re)processing. Depending on the intended application, the degradation of the polymeric structure of a product occurs seldom as a consequence of its use. For instance, having a lifespan typically shorter than one year, post-consumer plastic packaging is less susceptible to degradation by use [105]. On the other hand, contamination may have different origins and is generally referring to polymeric sources-e.g., the case of polymeric cross-contamination - or foreign sources-as in the case of impurities or the presence of non-intentionally added substances (NIAS), resulting from the degradation of additives [106].

Material contamination and degradation can occur throughout the different steps of the plastics value chain, including the waste processing stage. Among the existing literature, the aspect of how and to which extent every single step of the value chain contributes to contaminating and/or degrading the material still remains unexplored [107].

The adequacy of the input material for recycling could be realised by incorporating systems that are capable of controlling and determining the material's quality deterioration. For instance, the inclusion of a separate collection of materials based on the material type and/or their application can provide higher collection efficiencies with the enhanced quality of the material [73]. In addition, advanced sorting technologies can enhance the sorting yields and purity [108-111].

Additional quality maintenance to the recycled materials can come in the form of precautionary actions, through identifying contaminants and their possible sources in the plastic waste fraction. This will provide a better-designed management system for plastic waste $[106,112]$. Consequently, the application of circular economy could be boosted in the plastic waste stream, while ensuring the sustainability, high quality, and safety of products [67]. Another factor to be considered is the heterogeneity of plastic products available on the market in response to their intended applications and design requirements [25].

All in all, the mentioned aspects impacting the quality of recycled plastic materials are elaborated in the sections below.

\subsection{Product's Designs}

Plastics are made from an array of polymers, with combinations of different materials. Additionally, plastic's quality is modified by applying specific chemicals (e.g., colourants, additives, etc.) to meet manufacturers' functional and marketing demands [113]. Heterogenous designs obstruct the effective sorting of plastics, owing to the existence of countless colours, having different labelling materials that are hard to distinguish and remove, multilayer and multi-component packages, etc. Additionally, the vast number of additives used in different products adds to the heterogeneity of the plastic waste stream [23], resulting in an unfeasible and environmentally challenging recycling process, and consequently affecting the quality of recycled plastic [114].

Currently, there is limited mechanical recycling of multi-layer and multi-component products, because of the cross-contamination between the different types and degrees of materials and polymers. In this case, the products' designs interfere with the closed-loop recycling of the material and prevent higher recycling quotas [1,115]. Next to the issues arising from the combination of different polymeric and non-polymeric materials, major 
limitations in the polymers' recyclability result to be inherent to the material, owing to its structural composition. In this sense, additives have proven to be a source of contamination generating organic substances, the behaviour of which is still under investigation $[116,117]$. The presence of these substances per se does not represent a recyclability burden. Nonetheless, the effects are exacerbated once they have to endure thermal processes, for instance, during extrusion or blow moulding.

The lack of information on the amounts, natures, degradation mechanisms, and safety of the additives used for polymer processing [118] is one of the main reasons why the design of packaging is central in the plastic packaging's Circular Economy narrative. Consequently, its role as an outliner of the quantity-quality trade-off is also pivotal: Defining the level of recyclability of a packaging (for the combination of materials used, as well as its inherent structural composition) is a precondition to be able to foresee quality losses or gains in view of the increased quality of the recycled material. In other words, knowing how the material will behave at the re-processing stage (by having full information on how it has been designed) allows envisioning the best management options for that material to be fully recovered.

Improved products' designs will result in higher recycling rates, higher amounts and enhanced quality of recycled materials, and, consequently, will deliver higher value for the recycling industry [113]. In this context, two concepts-one more preferred than the other-have been developed throughout the years and are thoroughly reported in literature: Design for Recycling and Design from Recycling. Design for Recycling is an upstream approach, where the choice of materials, their combination, and the overall design strategy is made with the perspective of reducing the product's impact through its entire life cycle [119]. Following this tendency, many organisations have published Design for Recycling Guidelines for different packaging applications [120-123].

Veelaert et al. [21] define Design from Recycling as a design strategy that starts from the technical properties and characteristics of the recycled materials [21,124,125]. One might see this option as not necessarily favoured by the producers, in that it would require both an adaptation of the manufacturing infrastructure as well as of their marketing strategies (colour, shapes, labelling, etc.). Nevertheless, on the market, there are few examples of consumers' products following this rationale [126].

\subsection{Collection and Sorting of the Waste Stream}

Plastic waste collection and sorting are key steps in the mechanical recycling process [127], as they come at the beginning of the mechanical recycling chain and consequently define the quantities and the complexity of the material sent for recycling. The current recycling schemes for post-consumer waste focus on an efficient and clean separation of post-consumer packaging waste (including PET water bottles and polyolefin packaging material) $[128,129]$. Collecting waste via source separation waste collection systems is an essential part of increasing resource efficiency, achieving European recycling targets, and closing the loop in a circular economy [130]. The collection of plastic wastes can be conducted by bring-schemes, including the deposit refund system-DRS (e.g., for PET bottles) or through kerbside collection (plastic packaging material that is not included in the deposit systems) [1]. Many countries have a DRS in place targeting particularly PET bottles (in addition to glass bottles and aluminium cans), and they have proven high collection rates [131]. In 2017 in Germany, 97.3\% of the PET bottles put on the market for DRS were recovered, whereas $96.2 \%$ were materially recycled and transformed into recycled material for food packaging, fibres, or films [132].

While collection and sorting are crucial steps to retain high-value materials, the currently available infrastructures are not uniform within cities and countries. Generally, the infrastructure needs to be restructured to enable high-quality recycling [114]. 


\subsection{Contaminants}

The primary sources of contaminants in plastics across the plastics' value chain were summarised by Pivnenko et al. [133]. They include additives, polymer cross-contamination, non-polymer impurities, and products generated by polymer degradation. Contamination occurs in all stages of the value chain except for the extraction process. Contamination starts with the production step (by additives). Most of the contamination occurs during the manufacturing step (due to design requirements: multi-layers, multi-components, labels, and inks) [134]. Further contamination occurs during the application stage (mostly non-polymer impurities as well as degradation products) [135], segregation (polymer crosscontamination and non-polymer impurities), collection (polymer cross-contamination), sorting (polymer cross-contamination), and re-processing (as a consequence of degradation) [72]. Among the numerous contaminants in plastics are the chemical additives that are added to provide predefined qualities for application and marketing needs $[86,136,137]$.

\subsubsection{Additives in Plastics}

The polymer resins are usually mixed with other chemical substances (i.e., additives) and are hardly used as pure polymers $[15,138]$. Additives for plastics are substances that are dispersed within the polymeric matrix to improve their properties. This can be associated with minor to no change in the chemical structure of the polymer. Additives can be the most expensive components of a formulation [139] and are either physical property enhancers (e.g., plasticisers, lubricants, fillers, colourants, blowing agents, and antistatic agents) or protecting agents (e.g., heat and ultraviolet stabilisers, antioxidants, and flame retardants) $[137,140,141]$. The classification of additives for plastics manufacturing could be performed based on their function [142,143]:

- Functional additives (e.g., cross-linkers, hardeners, plasticisers, flame retardants, stabilisers, blowing agents, UV stabilisers, etc.);

- Colourants (e.g., carbon black (black), titanium dioxide (white), and various inorganic oxides);

- Fillers (e.g., silica, calcium carbonate, talc, carbon black, zinc oxide, titanium dioxide, etc.);

- Reinforcements.

The first comprehensive overview was published in 2019 by the European Chemical Agency (ECHA), which identified about 1550 additives that have been registered at 100 tonnes per year [143].

\subsubsection{The Fate of Additives in the Plastic Waste Stream}

Some additives may possess potential toxic properties (e.g., lead and tributyl tin in PVC), yet the extent to which the additives are released and migrate from plastics matrices still remains an unresolved issue. The main question is: What are the types and concentrations of additives in plastics that could be taken up and accumulated by living organisms $[139,144]$ ?

In order to evaluate the impact of additives in plastics, the risk of exposure to different chemicals as well as the routes and limits of exposure to these chemicals need first to be assessed [145]. An example of this is the debate on antimony trioxide $\left(\mathrm{Sb}_{2} \mathrm{O}_{3}\right)$ in PET bottles. A total daily intake limit (TDI) of antimony was established by the World Health Organization [146] to be $6 \mu \mathrm{g} \mathrm{kg}^{-1}$ of body mass. The possible risk of antimony intake from bottled water is an intensively studied subject. On this matter, Filella [147] critically reviewed 192 studies, addressing their scope, objectives, and, most importantly, the analytical methodologies applied and the statistical evaluations made. While strongly calling for a more rigorous experimental design (e.g., in the use of certified reference materials, the adequacy of the sample's size and its representativeness, the lack of adaptation of the analyte concentration to the limit of detection of the used technique-typically ICP-MS), the author confirms a few facts reported in literature. Antimony in PET water battles originates from the polymer itself, and, when the bottle is heated at temperatures above $70{ }^{\circ} \mathrm{C}$, antimony leaches. The same study confirmed that the levels of antimony in bottled 
water are mostly below regulatory thresholds [147]. In this sense, in order to reach the TDI, bottled water consumption has to reach 300 L per day, which is unrealistically high [139].

Additives of specific concern are phthalate plasticisers, bisphenol A (BPA), alkylphenols, organotin compounds, brominated flame retardants, and antimicrobial substances. These substances could be found in numerous mass-produced goods, e.g., medical devices, packaging and food packaging, perfumes and cosmetics, construction materials, and electronics $[139,148,149]$. For example, the composition of phthalates may reach up to $50 \%$ of the total mass of PVC plastics [150], where the global PVC production reached 44.3 Mt in 2018 and is expected to reach $59.7 \mathrm{Mt}$ by 2025 [151]. Phthalates, organotin, and BPA may be released to the environment during the service life of the plastics or after their end-of-life and processing [148,152].

There is substantial concern about the negative impacts of additives in plastics on wildlife and humans [144,153]. Existing patterns of plastics applications are creating global waste management problems, where plastic wastes have to be treated after their end-of-life. Plastic wastes transmit chemical additives, and despite the different treatment pathways, these additives are sooner or later transported and accumulated in the environment [15,69-71,138,154,155].

The potential migration and emission of additives from the polymeric structure should be considered, primarily when recycling is targeted.

The mechanism of additive migration takes place when the additive travels from the polymeric matrix to the surface of the plastic item from where it could be washed out. Thus, plastics with lower thicknesses usually promote higher potentials of additives migration [142]. The relationship between the polymer porous structure and the additive is a key factor affecting the migration mechanism. Namely, additives of smaller molecules (i.e., with lower molecular weight) have a higher tendency of migration [148]. For instance, the polymer's crystallinity and the orientation of the spherulites play a crucial role in the antimony's diffusion mechanisms from the PET structure [147]. A polymer with low crystallinity (e.g., PVC) facilitates the mobility of additives [142]. Apart from the molecular size of the additive, the nature of the additive can significantly influence its movement in and from the polymeric matrix; non-reactive additives are not chemically bonded. Hence, the tendency of migration can be greater [139]. Conversely, a higher solubility of additives in the polymeric structure can hinder their migration. Further factors can influence the migration of additives, including the additive's initial concentration and the surrounding temperature. Elevated temperatures $(\mathrm{T})$ and high initial concentrations $\left(\mathrm{C}_{0}\right)$ will directly influence additive migration, in accordance with Equation (1). Equation (1) combines Fick's law (flux) and the Arrhenius equation (temperature-dependent reaction rates) [142] as follows:

$$
\mathrm{M}=\mathrm{C}_{0} \times \mathrm{t}^{0.5} \times \mathrm{K} \times \operatorname{Exp}^{\frac{-\mathrm{E}}{\mathrm{RT}}}
$$

where:

M: Total migration;

$\mathrm{C}_{0}$ : Initial concentration of the chemical substance;

t: Time;

K: Constant;

T: Temperature;

E: Activation energy;

R: Gas constant.

During mechanical recycling, additives in plastics are circulated to new products, resulting in the accumulation of chemical substances that might be banned. For example, numerous items in end-of-life (EOL) flows were found to contain traces of banned chemicals and sometimes with concentrations exceeding the threshold limits [156]. Furthermore, a study conducted by Turner [24] showed that restricted trace elements, frequently found in WEEE plastics, were present in black packaging and trays for food products.

In order to assess the extent of additives circulation in the plastics circular economy concept, the fate of chemicals by mechanical recycling was assessed by Hansen et al. [142]. 
This was performed by studying the physicochemical properties of the substances and evaluating the impact of the conditions applied during plastic re-processing. It was judged that the dominant fraction of additives would remain in recycled plastics. Conversely, solvents that easily evaporate, monomers that further react during the recycling process, and stabilisers (heat stabilisers) that are forced to react by the recycling process will not remain in the plastic cycle when plastics are mechanically recycled [142].

The fate of additives by recycling differs from one plastic-type to another, depending on the treatment method applied for each resin, e.g., PE, PP, and PET can be mechanically recycled where PUR can only be recycled by feed-stock recycling or energy recovery. Therefore, the additives' fates could be correspondingly predicted. Energy recovery and feedstock recycling result in liberating the additives from the polymer's matrix, and the highest fraction of additives could mobilise and possibly leak out [157]. Table 1 provides a summary of the commercially available plastics, their recycling potential, and the risks associated with incineration. The method applied for the EOL treatment for these commercially available plastics indicates the fate of the incorporated additives. Table 2 in turn summarises the fate of additives of interest in plastics.

Table 1. A summary of the waste treatment potentials for commercially available plastics. Sources of data [5,158,159].

\begin{tabular}{|c|c|c|c|c|c|}
\hline Plastic Type & Critical Ingredients & $\begin{array}{l}\text { Recycling } \\
\text { Potential }\end{array}$ & $\begin{array}{c}\mathrm{CO}_{2} \text { Saving } \\
\text { through Recycling }\end{array}$ & $\begin{array}{l}\text { What Happens } \\
\text { by Incineration? }\end{array}$ & $\begin{array}{c}\text { Most Probable } \\
\text { Fate of Additives }\end{array}$ \\
\hline $\begin{array}{l}\text { Polyethylene } \\
\text { terephthalate } \\
\text { (PET) }\end{array}$ & $\begin{array}{l}\text { None; PET does not } \\
\text { contain plasticisers. } \\
\text { Terephthalate } \\
\text { compounds in PET are } \\
\text { not volatile. } \\
\text { Antimony is present in } \\
\text { negligible concentrations. }\end{array}$ & $\begin{array}{l}\text { Can endure up to } \\
8 \text { recycling cycles. } \\
\text { PET is turned into } \\
\text { fibres, films, } \\
\text { bottles, etc. }\end{array}$ & $\begin{array}{l}\text { Recycling } \\
\text { produces } 82 \% \text { less } \\
\mathrm{CO}_{2} \text { than the } \\
\text { production } \\
\text { of new PET } \\
\text { (transportation is } \\
\text { considered). }\end{array}$ & $\begin{array}{l}\text { Residue-free } \\
\text { combustion. } \\
\text { If FRs-free, only } \\
\mathrm{CO}_{2} \text { and } \mathrm{H}_{2} \mathrm{O} \\
\text { are produced. }\end{array}$ & $\begin{array}{l}\text { Transmitted to new } \\
\text { products when } \\
\text { recycled, unless it } \\
\text { has volatile or } \\
\text { reactive properties. }\end{array}$ \\
\hline $\begin{array}{l}\text { Polyethylene } \\
\text { (PE) }\end{array}$ & $\begin{array}{l}\text { Plasticisers are } \\
\text { not required. }\end{array}$ & $\begin{array}{l}4 \text { to } 5 \text { times; the } \\
\text { decrease in } \\
\text { polymeric chains' } \\
\text { length will prevent } \\
\text { further recycling. }\end{array}$ & $\begin{array}{c}\text { Recycling } \\
\text { produces } 20-70 \% \\
\text { less } \mathrm{CO}_{2} \text { than } \\
\text { manufacturing } \\
\text { new PE. }\end{array}$ & \multirow{2}{*}{$\begin{array}{c}\text { Residue-free } \\
\text { combustion. } \\
\text { If FRs-free, only } \\
\mathrm{CO}_{2} \text { and } \mathrm{H}_{2} \mathrm{O} \text { are } \\
\text { produced. } \\
\text { Hydrated } \\
\text { aluminium oxides } \\
\text { are the most used } \\
\text { FRs; from a } \\
\text { quantitative } \\
\text { standpoint, they } \\
\text { are ecologically } \\
\text { safe. }\end{array}$} & $\begin{array}{l}\text { Transmitted to new } \\
\text { products when } \\
\text { recycled, unless it } \\
\text { has volatile or } \\
\text { reactive properties. }\end{array}$ \\
\hline $\begin{array}{l}\text { Polypropylene } \\
\text { (PP) }\end{array}$ & $\begin{array}{l}\text { The use of plasticisers } \\
\text { is uncommon. }\end{array}$ & $\begin{array}{c}\text { PP can be recycled, } \\
\text { but it is } \\
\text { not extensively } \\
\text { applied. When PP } \\
\text { is melted down, a } \\
\text { mixture of various } \\
\text { PP types } \\
\text { is produced, } \\
\text { delivering } \\
\text { low-quality of } \\
\text { recycled material. }\end{array}$ & $\begin{array}{c}\text { Recycling } \\
\text { produces } 20-70 \% \\
\text { less } \mathrm{CO}_{2} \text { than } \\
\text { manufacturing } \\
\text { new PP. }\end{array}$ & & $\begin{array}{l}\text { Mostly liberated to } \\
\text { the environment } \\
\text { (for the incinerated } \\
\text { fraction). When } \\
\text { mechanically } \\
\text { recycled, the } \\
\text { additives are } \\
\text { transmitted to } \\
\text { new products. }\end{array}$ \\
\hline $\begin{array}{l}\text { PE-PET } \\
\text { multi-layer } \\
\text { films }\end{array}$ & None & $\begin{array}{l}\text { Not stated. At the } \\
\text { current state, } \\
\text { multi-layers are } \\
\text { not yet recycled. }\end{array}$ & Not specified & $\begin{array}{l}\text { Residue-free } \\
\text { combustion. } \\
\text { If FRs-free, only } \\
\mathrm{CO}_{2} \text { and } \mathrm{H}_{2} \mathrm{O} \\
\text { are produced. }\end{array}$ & $\begin{array}{l}\text { No proven } \\
\text { recycling of the } \\
\text { material, hence, } \\
\text { additives are } \\
\text { liberated to } \\
\text { the environment. }\end{array}$ \\
\hline $\begin{array}{l}\text { Polystyrene } \\
\text { (PS) }\end{array}$ & $\begin{array}{l}\text { P-nonylphenol is } \\
\text { partly used as a } \\
\text { stabiliser for PS; a } \\
\text { substance with } \\
\text { estrogen-like activity. }\end{array}$ & $\begin{array}{l}\text { Poor recyclability. } \\
\text { PS can be } \\
\text { converted into the } \\
\text { starting material } \\
\text { styrene by heating. }\end{array}$ & $\begin{array}{l}\text { No available } \\
\text { information. }\end{array}$ & $\begin{array}{l}\text { PS usually } \\
\text { contains additives } \\
\text { (e.g., FRs). Hence, } \\
\text { pungent and } \\
\text { harmful odours } \\
\text { are foreseen. }\end{array}$ & $\begin{array}{l}\text { Additives are } \\
\text { liberated to } \\
\text { the environment. }\end{array}$ \\
\hline
\end{tabular}


Table 1. Cont.

\begin{tabular}{|c|c|c|c|c|c|}
\hline Plastic Type & Critical Ingredients & $\begin{array}{l}\text { Recycling } \\
\text { Potential }\end{array}$ & $\begin{array}{c}\mathrm{CO}_{2} \text { Saving } \\
\text { through Recycling }\end{array}$ & $\begin{array}{l}\text { What Happens } \\
\text { by Incineration? }\end{array}$ & $\begin{array}{c}\text { Most Probable } \\
\text { Fate of Additives }\end{array}$ \\
\hline $\begin{array}{c}\text { Polyvinyl } \\
\text { chloride (PVC) }\end{array}$ & $\begin{array}{l}\text { Usually phthalates. } \\
\text { Sometimes } \\
\text { p-nonylphenol and } \\
\text { BPA, other so-called } \\
\text { endocrine disrupters } \\
\text { (hormone-like } \\
\text { substances). }\end{array}$ & $\begin{array}{l}\text { Germany has } \\
\text { widespread } \\
\text { take-back systems } \\
\text { of the PVC } \\
\text { processing } \\
\text { industry for rigid } \\
\text { PVC construction } \\
\text { material. }\end{array}$ & $\begin{array}{l}\text { No available } \\
\text { information. }\end{array}$ & $\begin{array}{l}\text { Forms corrosive } \\
\text { hydrogen chloride } \\
\text { gas, becomes } \\
\text { hydrochloric acid } \\
\text { with water. This is } \\
\text { neutralised with lime. } \\
\text { Toxic dioxins may } \\
\text { be formed. } \\
\text { If incineration is } \\
\text { incomplete, smoke } \\
\text { and soot may } \\
\text { contain toxic } \\
\text { poly-condensed } \\
\text { aromatics. }\end{array}$ & $\begin{array}{l}\text { Mostly liberated to } \\
\text { the environment. }\end{array}$ \\
\hline
\end{tabular}

FR: Flame retardants.

When closed-loop production is discussed, it is proposed that all incorporated substances are going to follow the same route of the recycled material. However, there are many factors affecting the circularity of additive chemicals, as summarised below:

- The interaction between the additive and the polymer: chemically bound (reactive) or not (additive). Reactive substances are harder to migrate, and they are potentially maintained in the plastics cycle by the mechanical recycling process $[23,160]$;

- The molecular weight of the substance: the higher the molecular weight of a substance, the lower its tendency for chemical migration [161];

- The boiling point of the substance: the higher the boiling point, the more stable it is. Hence, it is predicted that it will be transported to recycled products. On the other hand, when the boiling point is lower than what is applied during the mechanical recycling process, the substance is mostly lost by evaporation [142];

- Vapour pressure (volatility): the higher the volatility, the easier the migration [142];

- Water solubility: the water solubility defines a substance's tendency to migrate by washing; substances with higher water solubility are predicted to be lost [5];

- Additive solubility in plastics: this factor is opposing the previous one. The higher the solubility of the additive in the plastic matrix, the stronger the bonding. In other words, the chemical follows closed-loop recycling [142];

- The conditions applied during mechanical recycling: plastics mechanical recycling involves different steps, including washing, drying, shredding, and extruding. All these steps expose the material to heat and mechanical stress, which can aid in a partial or complete release of additives, depending on the physical and chemical properties of the additive [5].

Table 2. A summary of the fate of additives of interest in plastics.

\begin{tabular}{|c|c|c|c|c|c|}
\hline Substance & Function & $\begin{array}{c}\text { Relevant Types } \\
\text { of Plastics }\end{array}$ & $\begin{array}{l}\text { Potential Release } \\
\text { from Plastics }\end{array}$ & $\begin{array}{c}\text { Fate of the Ingredient } \\
\text { by Recycling }\end{array}$ & Resource \\
\hline $\begin{array}{l}\text { Cadmium }(\mathrm{Cd}) \\
\text { and cadmium } \\
\text { compounds }\end{array}$ & $\begin{array}{l}\text { Pigments: colours include } \\
\text { yellow, orange, red, and all } \\
\text { other derived colours; heat } \\
\text { and UV stabiliser in PVC. }\end{array}$ & $\begin{array}{l}\text { Cadmium pigments } \\
\text { may be found in all } \\
\text { types of resins. } \\
\text { Cadmium stabilisers } \\
\text { are mainly } \\
\text { used in PVC. }\end{array}$ & \multirow{2}{*}{$\begin{array}{l}\text { This element and its } \\
\text { compounds are solid } \\
\text { bound in plastics. } \\
\text { Release only by wear } \\
\text { and tear of products } \\
\text { (insignificant } \\
\text { quantity may } \\
\text { be released). }\end{array}$} & $\begin{array}{l}\text { Cd pigments and stabilisers } \\
\text { are solid bound; they will } \\
\text { continue to exist in the } \\
\text { plastics cycle when } \\
\text { mechanically recycled. }\end{array}$ & [142] \\
\hline $\begin{array}{l}\text { Chromium }(\mathrm{Cr}) \text { and } \\
\text { chromium } \\
\text { compounds }\end{array}$ & $\begin{array}{l}\text { Catalyst for the production } \\
\text { of plastics (chromium } \\
\text { trioxide); in pigments } \\
\text { (yellow, red, and green). }\end{array}$ & $\begin{array}{l}\text { PVC, PE, PP, and } \\
\text { other non-specified } \\
\text { plastics. }\end{array}$ & & $\begin{array}{c}\text { Cr pigments will remain in } \\
\text { the plastics' cycle by } \\
\text { mechanical recycling. }\end{array}$ & {$[142,162]$} \\
\hline
\end{tabular}


Table 2. Cont.

\begin{tabular}{|c|c|c|c|c|c|}
\hline Substance & Function & $\begin{array}{l}\text { Relevant Types } \\
\text { of Plastics }\end{array}$ & $\begin{array}{l}\text { Potential Release } \\
\text { from Plastics }\end{array}$ & $\begin{array}{c}\text { Fate of the Ingredient } \\
\text { by Recycling }\end{array}$ & Resource \\
\hline Chromium trioxide & $\begin{array}{l}\text { Catalyst for production of } \\
\text { plastics; intermediate for } \\
\text { manufacturing of pigments. }\end{array}$ & PE and other plastics. & $\begin{array}{l}\text { Mostly solid bound; } \\
\text { insignificant fractions } \\
\text { may be lost only by } \\
\text { wear and tear. }\end{array}$ & $\begin{array}{l}\text { Cr compounds will stay in } \\
\text { the plastics' cycle by } \\
\text { mechanical recycling. }\end{array}$ & [162] \\
\hline Cobalt(II) diacetate & $\begin{array}{l}\text { Pigment for tinting PET a } \\
\text { bluish colour (phased-out); } \\
\text { catalyst, e.g., in the } \\
\text { production of Purified } \\
\text { Terephthalate Acid, an } \\
\text { intermediate for } \\
\text { polyester fibre). }\end{array}$ & Polyester (PET). & $\begin{array}{l}\text { It is not expected to } \\
\text { migrate (it is solid } \\
\text { bound). Release only } \\
\text { by wear and tear of } \\
\text { plastics. The } \\
\text { potential for release } \\
\text { from plastics } \\
\text { is trivial. }\end{array}$ & $\begin{array}{l}\text { It will be sustained in the } \\
\text { plastics' cycle when } \\
\text { mechanically recycled, but } \\
\text { a minor amount may be } \\
\text { washed out due to the high } \\
\text { water solubility. }\end{array}$ & [163] \\
\hline $\begin{array}{l}\text { Lead }(\mathrm{Pb}) \text { and } \\
\text { lead compounds }\end{array}$ & $\begin{array}{l}\text { Heat and UV stabiliser for } \\
\text { PVC ( } 50 \% \text { of all stabilisers } \\
\text { are consumed } \\
\text { in PVC); pigments. }\end{array}$ & $\begin{array}{l}\mathrm{Pb} \text { stabilisers are } \\
\text { used in PVC. } \\
\mathrm{Pb} \text { pigments may be } \\
\text { used in all } \\
\text { types of resins. }\end{array}$ & $\begin{array}{l}\text { It is solid bound. Its } \\
\text { insignificant release } \\
\text { can only happen by } \\
\text { wear and tear. }\end{array}$ & $\begin{array}{l}\text { It will remain in the plastics' } \\
\text { cycle by mechanical } \\
\text { recycling. }\end{array}$ & [164] \\
\hline $\begin{array}{l}\text { Mercury }(\mathrm{Hg}) \text { and } \\
\text { mercury compounds }\end{array}$ & Used as a catalyst. & Polyurethane (PUR). & $\begin{array}{l}\text { Mercury compounds } \\
\text { are not chemically } \\
\text { bound and will } \\
\text { migrate. Elemental } \\
\text { mercury will } \\
\text { vaporise from the } \\
\text { plastic material. } \\
\end{array}$ & $\begin{array}{l}\text { PUR can only be recycled } \\
\text { by energy recovery or } \\
\text { feed-stock recycling. Most } \\
\text { mercury will probably } \\
\text { evaporate. Unknown fates } \\
\text { of Hg by } \\
\text { chemical recycling. }\end{array}$ & [165] \\
\hline $\begin{array}{l}\text { Brominated flame } \\
\text { retardants (BFRs) }\end{array}$ & Flame retardants. & $\begin{array}{l}\text { ABS, EPS, HIPS, PA, } \\
\text { PBT, PE, PP, epoxy, } \\
\text { unsaturated } \\
\text { polyesters, and PU. }\end{array}$ & $\begin{array}{l}\text { Flame retardants can } \\
\text { be either reactive or } \\
\text { additive. Only } \\
\text { additive flame } \\
\text { retardants will migrate. }\end{array}$ & $\begin{array}{l}\text { BFRs will probably remain } \\
\text { in mechanically recycled } \\
\text { plastics and decompose } \\
\text { by incineration. }\end{array}$ & [166-168] \\
\hline $\begin{array}{l}\text { Hexabromocyclododecane } \\
\text { (HBCDD) } \\
\text { and all major } \\
\text { diastereoisomers }\end{array}$ & Flame retardant. & $\begin{array}{l}\text { Expandable and } \\
\text { extruded polystyrene } \\
\text { (EPS and XPS), HIPS, } \\
\text { synthetic blends. }\end{array}$ & $\begin{array}{l}\text { HBCDD is not } \\
\text { chemically bound } \\
\text { and will migrate. }\end{array}$ & $\begin{array}{l}\text { There is a chance of partial } \\
\text { evaporation by recycling, } \\
\text { but mainly it will remain. It } \\
\text { will decay by incineration. }\end{array}$ & {$[142,169]$} \\
\hline $\begin{array}{l}\text { Ethylene (bistetrabro- } \\
\text { mophthalimide) } \\
\text { (EBTEBPI) }\end{array}$ & Flame retardant. & $\begin{array}{l}\text { HIPS, PE, PP, PBT, } \\
\text { OPET, PC, } \\
\text { and engineering } \\
\text { thermoplastics } \\
\text { in general }\end{array}$ & $\begin{array}{l}\text { High molecular } \\
\text { weight } \\
\left(951.5 \mathrm{~g} \mathrm{~mol}^{-1}\right) \text {, high } \\
\text { melting point } \\
\left(446^{\circ} \mathrm{C}\right) \text { and low } \\
\text { vapour pressure. } \\
\text { Hence, migration } \\
\text { is unlikely. }\end{array}$ & $\begin{array}{l}\text { It will mostly remain in the } \\
\text { recycled materials by } \\
\text { mechanical recycling. }\end{array}$ & {$[142,170]$} \\
\hline $\begin{array}{l}\text { Decabromodiphenyl } \\
\text { ethane (DBDPE) }\end{array}$ & Flame retardant. & $\begin{array}{l}\text { CPE, engineering } \\
\text { thermoplastic, HIPS, } \\
\text { PE, PP, thermosets. }\end{array}$ & $\begin{array}{l}\text { Due to the high } \\
\text { molecular weight } \\
\left(971 \mathrm{~g} \mathrm{~mol}^{-1}\right) \text { and } \\
\text { boiling point } \\
\left(676^{\circ} \mathrm{C}\right) \text {, migration } \\
\text { is unpredicted. }\end{array}$ & $\begin{array}{l}\text { It will mostly remain in the } \\
\text { recycled materials by } \\
\text { mechanical recycling. }\end{array}$ & {$[169,170]$} \\
\hline $\begin{array}{l}\text { Tetrabromobisphenol } \\
\text { A bis-(2,3- } \\
\text { dibromopropyl) ether } \\
\text { (TBBPA-BDBPE) }\end{array}$ & Flame retardant. & $\begin{array}{c}\text { ABS, HIPS, } \\
\text { Phenolic resins, } \\
\text { epoxy-laminates. }\end{array}$ & $\begin{array}{l}\text { It is chemically } \\
\text { bound (reactive FR); } \\
\text { release is limited. }\end{array}$ & \multirow{2}{*}{$\begin{array}{l}\text { These substances will } \\
\text { predominantly sustain in } \\
\text { the plastics cycle by } \\
\text { mechanical recycling, yet } \\
\text { they will decompose by } \\
\text { incineration. }\end{array}$} & {$[169,171,172]$} \\
\hline $\begin{array}{l}\text { Tris(tribromoneopentyl) } \\
\text { phosphate (TTBNPP) }\end{array}$ & Flame retardant. & PP. & $\begin{array}{l}\text { High molecular } \\
\text { weight } \\
\left(1019 \mathrm{~g} \mathrm{~mol}^{-1}\right) \\
\text { therefore, the } \\
\text { substance will } \\
\text { unlikely migrate. }\end{array}$ & & [173] \\
\hline
\end{tabular}


Table 2. Cont.

\begin{tabular}{|c|c|c|c|c|c|}
\hline Substance & Function & $\begin{array}{l}\text { Relevant Types } \\
\text { of Plastics }\end{array}$ & $\begin{array}{l}\text { Potential Release } \\
\text { from Plastics }\end{array}$ & $\begin{array}{c}\text { Fate of the Ingredient } \\
\text { by Recycling }\end{array}$ & Resource \\
\hline $\begin{array}{l}\text { Decabromodiphenyl } \\
\text { ethane (DBDPE) }\end{array}$ & Flame retardant. & $\begin{array}{l}\text { HIPS, PE, PP, } \\
\text { thermosets, and CPE. }\end{array}$ & $\begin{array}{l}\text { Migration is unlikely } \\
\text { due to the high } \\
\text { molecular weight } \\
\left(971.2 \mathrm{~g} \mathrm{~mol}^{-1}\right), \text { high } \\
\text { melting point } \\
\left(345^{\circ} \mathrm{C}\right) \text {, and low } \\
\text { vapour pressure. }\end{array}$ & $\begin{array}{l}\text { DBDPE will remain in } \\
\text { plastics when mechanically } \\
\text { recycled, but it will } \\
\text { decompose by incineration. }\end{array}$ & [169] \\
\hline $\begin{array}{l}\text { Antimony trioxide } \\
\qquad\left(\mathrm{Sb}_{2} \mathrm{O}_{3}\right)\end{array}$ & $\begin{array}{l}\text { Synergic flame } \\
\text { retardant, stabiliser. }\end{array}$ & Various plastics. & $\begin{array}{l}\text { It is solid bound } \\
\text { (inorganic) and } \\
\text { possibly will not } \\
\text { migrate. estimated to } \\
\text { be only liberated by } \\
\text { tear and wear. }\end{array}$ & $\begin{array}{l}\mathrm{Sb}_{2} \mathrm{O}_{3} \text { will be preserved in } \\
\text { plastics by mechanical } \\
\text { recycling, and it will } \\
\text { decompose by incineration. }\end{array}$ & {$[69,174,175]$} \\
\hline $\begin{array}{c}\text { Polycyclic aromatic } \\
\text { Hydrocarbons } \\
\text { (PAHs) }\end{array}$ & $\begin{array}{l}\text { They are impurities found } \\
\text { in plasticisers (e.g., mineral } \\
\text { oil and coal-based extender } \\
\text { oils) and carbon black. }\end{array}$ & $\begin{array}{l}\text { All black plastics. } \\
\text { Soft plasticised } \\
\text { plastics, and other } \\
\text { plastic types such as } \\
\text { ABS and PP. }\end{array}$ & $\begin{array}{l}\text { Some products have } \\
\text { substantial discharge } \\
\text { and thereby dermal } \\
\text { exposure can } \\
\text { be predicted. }\end{array}$ & $\begin{array}{l}\text { It will remain in the cycle } \\
\text { by mechanical recycling } \\
\text { due to the low mobility and } \\
\text { the high affinity to the } \\
\text { plastic matrix. }\end{array}$ & [176-178] \\
\hline
\end{tabular}

\subsection{Degradation}

Changes in plastics properties (e.g., mechanical, optical, thermal characteristics) are a result of polymer degradation. As an example, cracking, erosion, discolouration, and phase separation might be the consequences of chemical transformation, bond scission, and/or the formation of new oxidised groups [102,179]. Degradation can occur via various pathways and by numerous factors. The reason behind plastic degradation can be attributed to: (I) the plastic composition, especially when the migration of additives produces irreversible tacking and warping phenomena; (II) ageing, which results in chemical instability over time; (III) environmental factors such as light, high energy radiation (UV, gamma radiation), microorganisms (i.e., bacteria or fungi), temperature, and humidity; and (IV) the improper usage and cleaning of the objects (see Table 3) [102,110,180-182].

Table 3. Types of polymer degradation and the chief factors inducing degradation.

\begin{tabular}{|c|c|}
\hline Type of Degradation or Decomposition & Degrading Agent \\
\hline Photochemical degradation & Light (UV, visible light) \\
\hline High energy radiation-induced degradation & X-rays, gamma rays, fast electrons \\
\hline $\begin{array}{l}\text { Photo-thermal or photochemical, } \\
\text { ablative photo-degradation }\end{array}$ & Laser \\
\hline Electrical ageing & Electrical field \\
\hline Corrosive degradation, etching & Plasma \\
\hline Biological degradation & Microorganisms \\
\hline Mechanical degradation & Stress forces \\
\hline Physical degradation, environmental stress, cracking & Abrasive forces \\
\hline Ultrasonic degradation & Ultrasound \\
\hline Chemical degradation or decomposition, & Chemicals \\
\hline etching, solvolysis, hydrolysis & (acids, alkalis, salts, reactive gases, solvents, water) \\
\hline Thermal degradation or decomposition & Heat \\
\hline $\begin{array}{l}\text { Oxidation, oxidative degradation } \\
\text { and/or decomposition, ozonolysis }\end{array}$ & Oxygen, ozone \\
\hline $\begin{array}{l}\text { Thermo-oxidative degradation } \\
\text { and/or decomposition combustion }\end{array}$ & Heat and oxygen \\
\hline Photo-oxidation & Light and oxygen \\
\hline
\end{tabular}

The types of degradation can be classified into abiotic and biotic degradation $[183,184]$. Although the classification of polymer degradation slightly differs in the literature, in general, abiotic degradation involves chemical or physical and/or physicochemical degra- 
dation, whereas biotic degradation denotes biodegradation [181]. The rates of chemical and physical degradation of polymers are higher than those for biodegradation [185].

Polymers can be subject to degradation mechanisms (otherwise erosion) within the bulk material or on its surface [186]. During the former, two main mechanisms occur: chain scission and thermodynamic changes in state. Specifically, chain scission occurs in the material, with a consequent decrease in the molecular weight and, therefore, in its mechanical strength. The mass of the polymer decreases infinitesimally and at a much slower rate until it disintegrates. Bulk degradation can occur due to thermodynamically unstable states in the material, such as internal stresses, imperfect crystallisation, limited compatibility of the used additives with the polymer or incomplete polymerisation processes. Contrarily, during surface erosion, the loss of material only takes place on the surface of the polymer, which undergoes a reduction in its size and mass. In this case, the molecular weight and mechanical strength of the polymer remain practically unchanged [186]. Typically, surface degradation occurs when the material comes in contact with the external environment.

When degradation factors attack the polymer's surface, the polymer starts to gain a higher oxygen concentration. This step is described as the process of developing an 'oxidation skin'. As a result, fine cracks are formed on the polymer's surface, indicating morphological transformations. After that, degradation proceeds towards the inside of the polymer, with varying rates, depending on the diffusion rate. Observable changes in macroscopic properties occur suddenly after a certain time of degradation. The induction time leading to total failure of the polymer is generally determined as the time required to reach $50 \%$ deterioration of the original properties [181,187].

The degradation of plastic can produce chemical changes as well. As a consequence of these changes, new functional groups in the polymeric chains are formed, resulting in the plastic's contamination and variation in the polymeric grades. These contaminants (oxygenated fragments) become trapped in the solid-state of the polymer and may diffuse through the melt, hindering an effective reprocessing and affecting the product's quality $[110,115]$. Under the environmental ageing condition, oxidation and hydrolysis are considered chemical degradation mechanisms changing the macromolecular properties of polymers [184]. According to the lifecycle periods of polymers, the relevant processes are classified as melt degradation, long-term heat ageing, and weathering [188].

\section{Exploring Future Perspectives}

Resolving the plastic waste problem is a challenge that will require choosing from a large number of potential approaches and adapting them to the recycling needs of different plastics, applications, and regional waste management systems [189]. Plastic's quality deterioration is one of the main limitations to its closed-loop recycling. Identifying the quality deterioration factors of mechanically recycled plastics could help in applying the best practices to manage the plastic waste stream.

The future trend of literature is showing the interest towards a higher quality of recycled materials to meet the market's demands [22].

By publishing its Plastics Strategy, the EU commission has set ambitious targets to foster the introduction of higher quantities of recycled materials in plastic products. In this framework, the Circular Plastic Alliance responds to the call of implementing a minimum of 10 million tonnes of recycled plastics on the market, with several plastics users and producers subscribing a voluntary pledge to this common objective [190]. Along with this, the EU has also revised the calculation method for the recycling rates, which are now calculated in terms of the material entering the recycling facilities [191,192]. With these premises, an appeal common to all stakeholders of the plastics value chain-asking to find solutions to put on the market high quality recycled polymers-is steadily increasing [193].

As mentioned above, improvement prospects to enhance recycling lay on the plastic waste collection systems, the product design, recycling technologies, and the operational factors in the recycling plants [194]. Nonetheless, considerable potential exists particularly when a product's design is targeted (for instance, implementing design for recycling and 
design from recycling strategies), as well as if investments boost the development and scaleup of new sorting technologies [195-198]. The design for the recycling approach should first fulfil the functional requirements of the packaging, including barrier and mechanical properties and compromising with the marketing requirements $[199,200]$. Meanwhile, the packaging should be designed in such a way that it can be separated into mono-polymer streams through either NIR-spectroscopy or during the sink-float process [135].

As for those new optical sorting technologies for which interest is currently gaining momentum, VIS-sorting combined with AI-based image processing technologies represents one such technology [201-203]. There are already commercial robotic sorting solutions existing on the market [204,205]. The middle-infrared spectroscopy works in the range of $4000-600 \mathrm{~cm}^{-1}$ and is reported to be able to detect black material [206]. Flake-sorting by NIR in combination with colour detection cameras can further increase the purity of the material stream before the extrusion process [207-209].

New developments combining both aspects are striving for scaled-up application, combining digital marking, fluorescence-based markers, or NIR-detectable black pigments into the design phase of the product (typically for plastic products in the FMCG industry). These allow enhancing the identifiability of the product at the sorting stage [210-212]. Nonetheless, the feasibility to properly integrate new sorting technologies to existing plants as well as their contribution to the recycled material quantity-quality trade-off is still at a rudimental stage and needs to be fully assessed.

\section{Conclusions}

Despite the growing need for the implementation of sustainable approaches in treating the plastic waste stream, there are limitations slowing down the wide implementation of plastic waste recovery and recycling. Specifically, the challenges are based on three main pillars: economic investment, technical and technological innovation, and consumer behaviour.

In this paper, the focus was given to the technical limitations that are hindering plastic waste recycling, with the focus on the quality of recycled materials. Through this literature review, plastic quality deterioration by contamination, degradation, as well as products' designs and waste management practices were thoroughly discussed, highlighting their role as limiting factors for obtaining good quality material from mechanical recycling processes. In conclusion, the quality of recycled plastics is generally influenced by the heterogeneity of the recovered plastic feed as well as by the fluctuations in the quality of the material entering mechanical recycling processes. To improve the quality and feasibility of plastics recycling, the following should be considered: (a) working on enhanced products' designs for decreased waste heterogeneity and (b) controlling the materials' degree of contamination (e.g., by applying enhanced sorting).

Author Contributions: Conceptualization, A.A., C.P. and K.K.; methodology, A.A. and C.P.; resources, A.A., C.P., Z.K.C., J.G. and R.M.; writing-original draft preparation, A.A., C.P., Z.K.C., J.G. and R.M.; writing—review and editing, A.A. and C.P.; visualization, A.A. and C.P.; supervision, K.K. All authors have read and agreed to the published version of the manuscript.

Funding: This research received no external funding.

Informed Consent Statement: Not applicable.

Acknowledgments: We acknowledge the support for the Open Access fees by the Hamburg University of Technology (TUHH) in the funding program Open Access Publishing.

Conflicts of Interest: The authors declare no conflict of interest. 


\section{References}

1. Hopewell, J.; Dvorak, R.; Kosior, E. Plastics recycling: Challenges and opportunities. Philos. Trans. R. Soc. Lond. B Biol. Sci. 2009, 364, 2115-2126. [CrossRef]

2. Horodytska, O.; Valdés, F.J.; Fullana, A. Plastic flexible films waste management-A state of art review. Waste Manag. 2018, 77, 413-425. [CrossRef]

3. CONVERSIO Market \& Strategy. Global Plastics Flow 2018. Available online: https:/ / www.euromap.org (accessed on 11 January 2020).

4. Borrelle, S.B.; Ringma, J.; Law, K.L.; Monnahan, C.C.; Lebreton, L.; McGivern, A.; Murphy, E.; Jambeck, J.; Leonard, G.H.; Hilleary, M.A. Predicted growth in plastic waste exceeds efforts to mitigate plastic pollution. Science 2020, 369, 1515-1518. [CrossRef]

5. Alassali, A. Quality Deterioration Factors of the Plastics Closed-Loop Recycling. Ph.D. Thesis, Technische Universität, Hamburg, Germany, 2020.

6. PlasticsEurope. Plastics—the Facts-2017: An analysis of European Plasticsproduction, Demand and Waste Data. Available online: https:/ /www.plasticseurope.org/application/files/5715/1717/4180/Plastics_the_facts_2017_FINAL_for_website_one_ page.pdf (accessed on 24 October 2019).

7. Statista. Kunststoffabfallaufkommen und Recycelte Menge Kunststoff in Europa in Den Jahren 2006 bis 2018. Available online: https:/ / de.statista.com/statistik/daten/studie/206843/umfrage/kunststoffabfallaufkommen-und-recycelte-mengekunststoff-in-europa/ (accessed on 8 October 2019).

8. PlasticsEurope. Plastics—the Facts 2020: An Analysis of European Plastics Production, Demand and Waste Data. Available online: https: / / www.plasticseurope.org/en/resources/publications/4312-plastics-facts-2020 (accessed on 15 June 2021).

9. Geyer, R.; Jambeck, J.R.; Law, K.L. Production, use, and fate of all plastics ever made. Sci. Adv. 2017, 3, e1700782. [CrossRef] [PubMed]

10. CONVERSIO Market \& Strategy. Stoffstrombild Kunststoffe in Deutschland 2017: Kurzfassung. Available online: https: //www.bvse.de/images/news/Kunststoff/2018/181011_Kurzfassung_Stoffstrombild_2017.pdf (accessed on 22 April 2019).

11. Stenmarck, A.; Belleza, E.L.; Fråne, A.; Busch, N. Hazardous Substances in Plastics:-Ways to Increase Recycling; Nordic Council of Ministers: Copenhagen, Denmark, 2017; ISBN 9289348496.

12. Grigore, M.E. Methods of recycling, properties and applications of recycled thermoplastic polymers. Recycling 2017, 2, 24. [CrossRef]

13. Picuno, C.; Alassali, A.; Chong, Z.K.; Kuchta, K. Flows of post-consumer plastic packaging in Germany: An MFA-aided case study. Resour. Conserv. Recycl. 2021, 169, 105515. [CrossRef]

14. Brouwer, M.; Picuno, C.; van Thoden Velzen, E.U.; Kuchta, K.; de Meester, S.; Ragaert, K. The impact of collection portfolio expansion on key performance indicators of the Dutch recycling system for Post-Consumer Plastic Packaging Waste, a comparison between 2014 and 2017. Waste Manag. 2019, 100, 112-121. [CrossRef] [PubMed]

15. Alassali, A.; Barouta, D.; Tirion, H.; Moldt, Y.; Kuchta, K. Towards a high quality recycling of plastics from waste electrical and electronic equipment through separation of contaminated fractions. J. Hazard. Mater. 2019, 387, 121741. [CrossRef] [PubMed]

16. Camacho, W.; Karlsson, S. Quality-determination of recycled plastic packaging waste by identification of contaminants by GC-MS after microwave assisted extraction (MAE). Polym. Degrad. Stab. 2000, 71, 123-134. [CrossRef]

17. Dijkgraaf, E.; Gradus, R. Post-collection Separation of Plastic Waste: Better for the Environment and Lower Collection Costs? Environ. Resource Econ. 2020, 77, 127-142. [CrossRef]

18. Brouwer, M.; Thoden van Velzen, E.U.; Augustinus, A.; Soethoudt, H.; de Meester, S.; Ragaert, K. Predictive model for the Dutch post-consumer plastic packaging recycling system and implications for the circular economy. Waste Manag. 2018, 71, 62-85. [CrossRef] [PubMed]

19. Polymer Properties Database: Most Common Thermoplastics. Available online: http://polymerdatabase.com/polymer\%20 classes/Thermoplastics.html (accessed on 15 August 2021).

20. Da Silva, D.J.; Wiebeck, H. Current options for characterizing, sorting, and recycling polymeric waste. Prog. Rubber Plast. Recycl. Technol. 2020, 36, 284-303. [CrossRef]

21. Veelaert, L.; Du Bois, E.; Moons, I.; de Pelsmacker, P.; Hubo, S.; Ragaert, K. The Identity of Recycled Plastics: A Vocabulary of Perception. Sustainability 2020, 12, 1953. [CrossRef]

22. Hahladakis, J.N.; Iacovidou, E. Closing the loop on plastic packaging materials: What is quality and how does it affect their circularity? Sci. Total Environ. 2018, 630, 1394-1400. [CrossRef] [PubMed]

23. Hahladakis, J.N.; Velis, C.A.; Weber, R.; Iacovidou, E.; Purnell, P. An overview of chemical additives present in plastics: Migration, release, fate and environmental impact during their use, disposal and recycling. J. Hazard. Mater. 2018, 344, 179-199. [CrossRef] [PubMed]

24. Turner, A. Black plastics: Linear and circular economies, hazardous additives and marine pollution. Environ. Int. 2018, 117, 308-318. [CrossRef]

25. Eriksen, M.K.; Christiansen, J.D.; Daugaard, A.E.; Astrup, T.F. Closing the loop for PET, PE and PP waste from households: Influence of material properties and product design for plastic recycling. Waste Manag. 2019, 96, 75-85. [CrossRef] [PubMed]

26. European Commission. Communication from the Commission to the European Parliament, the Council, the European Economic and Social Committee and the Committee of the Regions. Closing the Loop-An EU Action Plan for the Circular Economy: COM(2015) 614 Final; European Commission, Ed.; European Commission: Brussels, Belgium, 2015. 
27. European Commission. Report from the Commission to the European Parliament, the Council, the European Economic and Social Committee and the Committee of the Regions on the Implementation of EU Waste Legislation, Including the Early Warning Report for Member States at Risk of Missing the 2020 Preparation for Re-Use/Recycling Targets on Municipal Waste: COM(2018) 656 Final; European Commission, Ed.; European Commission: Brussels, Belgium, 2018.

28. European Parliament. Paket zur Kreislaufwirtschaft: Neue EU-Recyclingziele; European Parliament: Strasbourg, France, 2017. (In German)

29. Iammartino, N.R. New routes tackle tough plastics-recycling jobs. Chem. Eng. 1976, 83, 54.

30. Wehrenberg, R.H. Plastics recycling-is it now commercially feasible. Mater. Eng. 1979, 89, 34-39.

31. Hansmann, J. Environmental-protection and plastics recycling. Gummi Asbest Kunststoffe 1980, 33, $784-787$.

32. Basta, N.; Stadig, W.; Short, H.; Ushio, S.; Kemezis, P.; Bolton, L.; Mcqueen, S. Plastics Recycling-A Revival; Mcgraw Hill Inc.: New York, NY, USA, 1984.

33. Basta, N. Plastics recycling grows up. Chem. Eng. 1987, 94, 22.

34. Brewer, G. Plastics Recycling Action Plan for Massachusetts; Massachusetts Department of Environmental Quality Engineering: Boston, MA, USA, 1988.

35. Thayer, A.M. Solid Waste Concerns Spur Plastic Recycling Efforts (in the US). Chem. Eng. News 1989, 67, 7-15. [CrossRef]

36. Basta, N.; Johnson, E. Plastics recycling picks up momentum. Chem. Eng. 1989, 96, 30.

37. Kline, C.H. Plastics recycling takes off in the USA. Chem. Ind. 1989, 15, 483-486.

38. Basta, N. Plastics Recycling Gains Momentum. Chem. Eng. 1990, 97, 37.

39. Reisch, M. Plastic recycling expansion planned. Chem. Eng. News 1990, 68, 5-6. [CrossRef]

40. McDonald, S.; Ball, R. Public participation in plastics recycling schemes. Resour. Conserv. Recycl. 1998, 22, 123-141. [CrossRef]

41. Drelich, J.; Payne, T.; Kim, J.H.; Miller, J.D.; Kobler, R.; Christiansen, S. Selective froth flotation of PVC from PVC/PET mixtures for the plastics recycling industry. Polym. Eng. Sci. 1998, 38, 1378-1386. [CrossRef]

42. Brandrup, J. How much plastics recycling can we afford? Kunststoffe-Plast Europe 1998, 88, 1778-1780.

43. Lin, C.C. (Ed.) Recycling Technology of Poly (Ethylene Terephthalate) Materials; Macromolecular Symposia; Wiley Online Library: Hoboken, NJ, USA, 1998.

44. Królikowski, B. Some technological problems encountered in the designing of plastics recycling machines and devices. Polimery 1999, 44, 269-274. [CrossRef]

45. Lin, H.-R.; Lin, C.-T. Mechanical Properties and Morphology of Recycled. Plastic Wastes by Solution Blending. Polym. Plast. Technol. Eng. 1999, 38, 1031-1050. [CrossRef]

46. Albano, C.; Sanchez, G. Study of the mechanical, thermal, and thermodegradative properties of virgin PP with recycled and non-recycled HDPE. Polym. Eng. Sci. 1999, 39, 1456-1462. [CrossRef]

47. Ahmed, N.; Khan, J.H.; Hussain, I.; Hamid, S.H. Thermal, chemical and mechanical property evaluation of recycled-reprocessed high density polyethylene. J. Polym. Mater. 1999, 16, 341-345.

48. Drelich, J.; Kim, J.H.; Payne, T.; Miller, J.D.; Kobler, R.W. Purification of polyethylene terephthalate from polyvinyl chloride by froth flotation for the plastics (soft-drink bottle) recycling industry. Sep. Purif. Technol. 1999, 15, 9-17. [CrossRef]

49. Allen, V.; Kalivas, J.H.; Rodriguez, R.G. Post-consumer plastic identification using Raman spectroscopy. Appl. Spectrosc. 1999, 53, 672-681. [CrossRef]

50. Ferrara, G.; Meloy, T.P. Low dense media process: A new process for low-density solid separation. Powder Technol. 1999, 103, 151-155. [CrossRef]

51. Milne, B.J.; Behie, L.A.; Berruti, F. Recycling of waste plastics by ultrapyrolysis using an internally circulating fluidized bed reactor. J. Anal. Appl. Pyrolysis 1999, 51, 157-166. [CrossRef]

52. Kartalis, C.N.; Papaspyrides, C.D.; Pfaendner, R.; Hoffmann, K.; Herbst, H. Mechanical recycling of postused high-density polyethylene crates using the restabilization technique. I. Influence of reprocessing. J. Appl. Polym. Sci. 1999, 73, 1775-1785. [CrossRef]

53. Kartalis, C.N.; Papaspyrides, C.D.; Pfaendner, R. Recycling of post-used PE packaging film using the restabilization technique. Polym. Degrad. Stab. 2000, 70, 189-197. [CrossRef]

54. Asanuma, M.; Ariyama, T.; Sato, M.; Murai, R.; Nonaka, T.; Okochi, I.; Tsukiji, H.; Nemoto, K. Development of waste plastics injection process in blast furnace. ISIJ Int. 2000, 40, 244-251. [CrossRef]

55. La Mantia, F.P. (Ed.) The Role of Additives in the Recycling of Polymers; Macromolecular Symposia; Wiley Online Library: Hoboken, NJ, USA, 1998.

56. Pedersen, T.H.; Conti, F. Improving the circular economy via hydrothermal processing of high-density waste plastics. Waste Manag. 2017, 68, 24-31. [CrossRef]

57. Pavlo, S.; Fabio, C.; Hakim, B.; Mauricio, C. (Eds.) 3D-Printing based distributed plastic recycling: A conceptual model for closed-loop supply chain design. In Proceedings of the 2018 IEEE International Conference on Engineering, Technology and Innovation (ICE/ITMC), Stuttgart, Germany, 17-20 June 2018.

58. Zhong, S.; Pearce, J.M. Tightening the loop on the circular economy: Coupled distributed recycling and manufacturing with recyclebot and RepRap 3-D printing. Resour. Conserv. Recycl. 2018, 128, 48-58. [CrossRef]

59. Milios, L.; Christensen, L.H.; McKinnon, D.; Christensen, C.; Rasch, M.K.; Eriksen, M.H. Plastic recycling in the Nordics: A value chain market analysis. Waste Manag. 2018, 76, 180-189. [CrossRef] 
60. Liu, Z.; Adams, M.; Cote, R.P.; Chen, Q.; Wu, R.; Wen, Z.; Liu, W.; Dong, L. How does circular economy respond to greenhouse gas emissions reduction: An analysis of Chinese plastic recycling industries. Renew. Sustain. Energy Rev. 2018, 91, 1162-1169. [CrossRef]

61. Rhodes, C.J. Solving the plastic problem: From cradle to grave, to reincarnation. Sci. Prog. 2019, 102, 218-248. [CrossRef]

62. Sarath, P.; Bonda, S.; Mohanty, S.; Nayak, S.K. Identification and thermomechanical characterization of polymers recovered from mobile phone waste. J. Mater. Cycles Waste Manag. 2017, 19, 1391-1399. [CrossRef]

63. Campolina, J.M.; Sigrist, C.S.L.; de Paiva, J.M.F.; Nunes, A.O.; da Silva Moris, V.A. A study on the environmental aspects of WEEE plastic recycling in a Brazilian company. Int. J. Life Cycle Assess. 2017, 22, 1957-1968. [CrossRef]

64. Tran, C.D.; Salhofer, S.P. Processes in informal end-processing of e-waste generated from personal computers in Vietnam. J. Mater. Cycles Waste Manag. 2018, 20, 1154-1178. [CrossRef]

65. Vazquez, Y.V.; Barbosa, S.E. Use of Acrylonitrile-Butadiene-Styrene from Waste Electric and Electronic Equipment without an accurate previous separation. Detritus 2018, 1, 2611-4135. [CrossRef]

66. Rentizelas, A.; Shpakova, A.; Mašek, O. Designing an optimised supply network for sustainable conversion of waste agricultural plastics into higher value products. J. Clean. Prod. 2018, 189, 683-700. [CrossRef]

67. Eriksen, M.K.; Pivnenko, K.; Olsson, M.E.; Astrup, T.F. Contamination in plastic recycling: Influence of metals on the quality of reprocessed plastic. Waste Manag. 2018, 79, 595-606. [CrossRef]

68. Grigorescu, R.M.; Ghioca, P.; Iancu, L.; Grigore, M.E.; Andrei, R.E.; Ion, R.M.; Nicolae, C.A.; Gabor, R. Composites of Styrenebutadiene Block-copolymers Reinforced with WEEE Polystyrene Fraction. Mater. Plast. 2019, 56, 510. [CrossRef]

69. Alassali, A.; Abis, M.; Fiore, S.; Kuchta, K. Classification of plastic waste originated from waste electric and electronic equipment based on the concentration of antimony. J. Hazard. Mater. 2019, 380, 120874. [CrossRef] [PubMed]

70. Alassali, A.; Picuno, C.; Samara, H.; Diedler, S.; Fiore, S.; Kuchta, K. Antimony mining from PET bottles and e-waste plastic fractions. Sustainability 2019, 11, 4021. [CrossRef]

71. Picuno, C.; Alassali, A.; Sundermann, M.; Godosi, Z.; Picuno, P.; Kuchta, K. Decontamination and recycling of agrochemical plastic packaging waste. J. Hazard. Mater. 2020, 381, 120965. [CrossRef] [PubMed]

72. Pivnenko, K. Waste Material Recycling: Assessment of Contaminants Limiting Recycling. Ph.D. Thesis, Technical University of Denmark, DTU, Kongens Lyngby, Denmark, 2016.

73. Vollmer, I.; Jenks, M.J.F.; Roelands, M.C.P.; White, R.J.; van Harmelen, T.; de Wild, P.; van der Laan, G.P.; Meirer, F.; Keurentjes, J.T.F.; Weckhuysen, B.M. Beyond mechanical recycling: Giving new life to plastic waste. Angew. Chem. Int. Ed. 2020, 59, 15402-15423. [CrossRef]

74. Carrete, I.A.; Quiñonez, P.A.; Bermudez, D.; Roberson, D.A. Incorporating textile-derived cellulose fibers for the strengthening of recycled polyethylene terephthalate for 3D printing feedstock materials. J. Polym. Environ. 2021, 29, 662-671. [CrossRef]

75. Mikula, K.; Skrzypczak, D.; Izydorczyk, G.; Warchoł, J.; Moustakas, K.; Chojnacka, K.; Witek-Krowiak, A. 3D printing filament as a second life of waste plastics-A review. Environ. Sci. Pollut. Res. 2020, 28, 12321-12333. [CrossRef]

76. Bishop, G.; Styles, D.; Lens, P.N.L. Recycling of European plastic is a pathway for plastic debris in the ocean. Environ. Int. 2020, 142, 105893. [CrossRef]

77. Almishal, S.S.I.; Mohamed, T.A.; Shazly, M. Experimental and statistical study of the effect of temperature and waste ratio on the mechanical properties and cost of polystyrene polypropylene plastic blends. Heliyon 2020, 6, e04166. [CrossRef]

78. Santander, P.; Sanchez, F.A.C.; Boudaoud, H.; Camargo, M. Closed loop supply chain network for local and distributed plastic recycling for 3D printing: A MILP-based optimization approach. Resour. Conserv. Recycl. 2020, 154, 104531. [CrossRef]

79. Umeda, Y.; Kitagawa, K.; Hirose, Y.; Akaho, K.; Sakai, Y.; Ohta, M. Potential Impacts of the European Union's Circular Economy Policy on Japanese Manufacturers. Int. J. Autom. Technol. 2020, 14, 857-866. [CrossRef]

80. Sasaki, S.; Watanabe, K.; Lee, K.; Widyaningsih, N.; Baek, Y.; Araki, T. Recycling contributions of dumpsite waste pickers in Bantar Gebang, Indonesia. J. Mater. Cycles Waste Manag. 2020, 22, 1662-1671. [CrossRef]

81. Schlitz, N. Environmental change and the informal plastic recycling networks of Kolkata. Singap. J. Trop. Geogr. 2020, 41, 450-467. [CrossRef]

82. Bonifazi, G.; Fiore, L.; Hennebert, P.; Serranti, S. Development of a selection system based on hyperspectral imaging for plastic waste with brominated flame retardants. Environ. Eng. Manag. J. 2020, 19, 1755-1763.

83. Gradus, R. Postcollection Separation of Plastic Recycling and Design-For-Recycling as Solutions to Low Cost-Effectiveness and Plastic Debris. Sustainability 2020, 12, 8415. [CrossRef]

84. Demets, R.; Roosen, M.; Vandermeersch, L.; Ragaert, K.; Walgraeve, C.; de Meester, S. Development and application of an analytical method to quantify odour removal in plastic waste recycling processes. Resour. Conserv. Recycl. 2020, $161,104907$. [CrossRef]

85. Kahlert, S.; Bening, C.R. Plastics recycling after the global pandemic: Resurgence or regression? Resour. Conserv. Recycl. 2020, 160, 104948. [CrossRef]

86. Sanchez, F.A.C.; Boudaoud, H.; Camargo, M.; Pearce, J.M. Plastic recycling in additive manufacturing: A systematic literature review and opportunities for the circular economy. J. Clean. Prod. 2020, 264, 121602. [CrossRef]

87. Zhang, Y.; Jiang, H.; Wang, H.; Wang, C. Separation of hazardous polyvinyl chloride from waste plastics by flotation assisted with surface modification of ammonium persulfate: Process and mechanism. J. Hazard. Mater. 2020, 389, 121918. [CrossRef] 
88. Bora, R.R.; Wang, R.; You, F. Waste Polypropylene Plastic Recycling toward Climate Change Mitigation and Circular Economy: Energy, Environmental, and Technoeconomic Perspectives. ACS Sustain. Chem. Eng. 2020, 8, 16350-16363. [CrossRef]

89. Solis, M.; Silveira, S. Technologies for chemical recycling of household plastics-A technical review and TRL assessment. Waste Manag. 2020, 105, 128-138. [CrossRef]

90. Kumagai, S.; Nakatani, J.; Saito, Y.; Fukushima, Y.; Yoshioka, T. Latest Trends and Challenges in Feedstock Recycling of Polyolefinic Plastics. J. Jpn. Pet. Inst. 2020, 63, 345-364. [CrossRef]

91. Murthy, K.; Shetty, R.J.; Shiva, K. Plastic waste conversion to fuel: A review on pyrolysis process and influence of operating parameters. Energy Sources Part A Recovery Util. Environ. Eff. 2020, 1-21. [CrossRef]

92. Lee, A.; Liew, M.S. Tertiary recycling of plastics waste: An analysis of feedstock, chemical and biological degradation methods J. Mater. Cycles Waste Manag. 2020, 23, 32-43. [CrossRef]

93. Feghali, E.; Tauk, L.; Ortiz, P.; Vanbroekhoven, K.; Eevers, W. Catalytic chemical recycling of biodegradable polyesters. Polym. Degrad. Stab. 2020, 179, 109241. [CrossRef]

94. Osman, A.I.; Farrell, C.; Al-Muhtaseb, A.H.; Al-Fatesh, A.S.; Harrison, J.; Rooney, D.W. Pyrolysis kinetic modelling of abundant plastic waste (PET) and in-situ emission monitoring. Environ. Sci. Eur. 2020, 32, 112. [CrossRef]

95. Miller, L.; Soulliere, K.; Sawyer-Beaulieu, S.; Tseng, S.; Tam, E. Challenges and alternatives to plastics recycling in the automotive sector. Waste Manag. Valorization 2017, 237-266.

96. Maletz, R. Assessment of Optimisation Measures in the Recirculation Process of Plastic Materials. Ph.D. Thesis, Technische Universität Dresden, Dresden, Germany, 2021.

97. Kirchherr, J.; Reike, D.; Hekkert, M. Conceptualizing the circular economy: An analysis of 114 definitions. Resour. Conserv. Recycl. 2017, 127, 221-232. [CrossRef]

98. Moser, H.; Fabian, M.; Jung, M.; Heutling, S.; Körber, G.; Oehme, I.; Wurbs, J.; KrauseII, S.; Kovacs, D.; KrügerII, F.; et al. UBA's Key Aspects to Increase Plastic Recycling and the Use of Recyclates. Available online: https:/ /www.umweltbundesamt.de/sites/ default/files/medien/377/publikationen/170601_uba_pos_kunststoffrecycling_engl_bf.pdf (accessed on 3 May 2021).

99. Mudgal, S.; Lyons, L. Study on an Increased Mechanical Recycling Target for Plastics. 2013. Available online: https://743c838022c6-4457-9895-11872f2a708a.filesusr.com/ugd/0af79c_622b367f2f52438c996694bdab97a7965.pdf (accessed on 3 May 2021).

100. Mudgal, S.; Lyons, L.; Kong, M.A.; André, N.; Monier, V.; Labouze, E. Assessment of Impacts of Options to Reduce the Use of Single-Use Plastic Carrier Bags. 2011. Available online: https:/ /ec.europa.eu/environment/pdf/waste/packaging/report_ options.pdf (accessed on 3 May 2021).

101. European Commission. Green Paper on a European Strategy on Plastic Waste in the Environment: COM (2013) 123 Final. 2013 Available online: https:/ / eur-lex.europa.eu/legal-content/EN/TXT/PDF/?uri=CELEX:52013DC0123\&from=EN (accessed on 3 May 2021).

102. Alassali, A.; Moon, H.; Picuno, C.; Meyer, R.S.; Kuchta, K. Assessment of polyethylene degradation after aging through anaerobic digestion and composting. Polym. Degrad. Stab. 2018, 158, 14-25. [CrossRef]

103. Saikrishnan, S.; Jubinville, D.; Tzoganakis, C.; Mekonnen, T.H. Thermo-mechanical degradation of polypropylene (PP) and low-density polyethylene (LDPE) blends exposed to simulated recycling. Polym. Degrad. Stab. 2020, 182, 109390. [CrossRef]

104. Muncke, J. Tackling the toxics in plastics packaging. PLoS Biol. 2021, 19, e3000961. [CrossRef]

105. Thoden van Velzen, E.U.; Chu, S.; Alvarado Chacon, F.; Brouwer, M.T.; Molenveld, K. The impact of impurities on the mechanical properties of recycled polyethylene. Packag. Technol. Sci. 2021, 34, 219-228. [CrossRef]

106. Horodytska, O.; Cabanes, A.; Fullana, A. Non-intentionally added substances (NIAS) in recycled plastics. Chemosphere 2020, 251, 126373. [CrossRef] [PubMed]

107. Picuno, C.; van Eygen, E.; Brouwer, M.T.; Kuchta, K.; van Thoden Velzen, E.U. Factors Shaping the Recycling Systems for Plastic Packaging Waste-A Comparison between Austria, Germany and The Netherlands. Sustainability 2021, 13, 6772. [CrossRef]

108. Brunner, S.; Fomin, P.; Kargel, C. Automated sorting of polymer flakes: Fluorescence labeling and development of a measurement system prototype. Waste Manag. 2015, 38, 49-60. [CrossRef] [PubMed]

109. Ruj, B.; Pandey, V.; Jash, P.; Srivastava, V.K. Sorting of plastic waste for effective recycling. Int. J. Appl. Sci. Eng. Res. 2015, 4, 564-571.

110. Alassali, A.; Fiore, S.; Kuchta, K. Assessment of plastic waste materials degradation through near infrared spectroscopy. Waste Manag. 2018, 82, 71-81. [CrossRef]

111. Woidasky, J.; Sander, I.; Schau, A.; Moesslein, J.; Wendler, P.; Wacker, D.; Gao, G.; Kirchenbauer, D.; Kumar, V.; Busko, D.; et al. Inorganic fluorescent marker materials for identification of post-consumer plastic packaging. Resour. Conserv. Recycl. 2020, $161,104976$. [CrossRef]

112. Singh, P.; Sharma, V.P. Integrated plastic waste management: Environmental and improved health approaches. Procedia Environ. Sci. 2016, 35, 692-700. [CrossRef]

113. European Commission. Communication from the Commission to the European Parliament, the Council, the European Economic and Social Committee and the Committee of the Regions. A European Strategy for Plastics in a Circular Economy: COM (2018) 28 Final; European Commission, Ed.; European Commission: Brussels, Belgium, 2018.

114. European Commission. Report from the Commission to the European Parliament, the Council, the European Economic and Social Committee and the Committee of the Regions on the implementation of the Circular Economy Action Plan: COM (2019) 190 Final; European Commission: Brussels, Belgium, 2019. 
115. Ragaert, K.; Delva, L.; van Geem, K. Mechanical and chemical recycling of solid plastic waste. Waste Manag. 2017, 69, 24-58. [CrossRef]

116. Kato, L.S.; Conte-Junior, C.A. Safety of plastic food packaging: The challenges about non-intentionally added substances (NIAS) discovery, identification and risk assessment. Polymers 2021, 13, 2077. [CrossRef]

117. Pivnenko, K.; Eriksen, M.K.; Martín-Fernández, J.A.; Eriksson, E.; Astrup, T.F. Recycling of plastic waste: Presence of phthalates in plastics from households and industry. Waste Manag. 2016, 54, 44-52. [CrossRef]

118. Iacovidou, E.; Velenturf, A.P.; Purnell, P. Quality of resources: A typology for supporting transitions towards resource efficiency using the single-use plastic bottle as an example. Scie. Total Environ. 2019, 647, 441-448. [CrossRef]

119. Maris, E.; Froelich, D.; Aoussat, A.; Naffrechoux, E. From Recycling to Eco-design. In Handbook of Recycling: From Recycling to Eco-Design; Maris, E., Froelich, D., Aoussat, A., Naffrechoux, E., Eds.; Elsevier: Amsterdam, The Netherlands, 2014; pp. 421-427, ISBN 9780123964595.

120. KIDV—Netherlands Institute for Sustainable Packaging. Improve the Recyclability of Packaging. Available online: https: / / recyclability.kidv.nl/ (accessed on 6 July 2021).

121. CEFLEX. Designing for a Circular Economy (D4ACE) Guidelines. Available online: https://guidelines.ceflex.eu/resources/ (accessed on 6 July 2021).

122. Plastic Recyclers Europe. Design for Recycling Guidelines: RecyClass. Available online: https://recyclass.eu/recyclass / designfor-recycling-guidelines / (accessed on 6 July 2021).

123. The Green Dot. Design4Recycling: RecylingCOMPASS. Available online: https://www.gruener-punkt.de/fileadmin/Dateien/ Downloads/PDFs/1909_D4R_Guide_DE.pdf (accessed on 6 July 2021).

124. Veelaert, L.; Du Bois, E.; van Doorselaer, K.; Hubo, S.; Ragaert, K. Manual Design for Recycling. 2017. Available online: https:/ / medialibrary.uantwerpen.be/oldcontent/container49257/files/Design\%20From\%20Recycling_Manual_English\% 20booklet.pdf (accessed on 6 July 2021).

125. Ragaert, K.; Huysveld, S.; Vyncke, G.; Hubo, S.; Veelaert, L.; Dewulf, J.; Du Bois, E. Design from recycling: A complex mixed plastic waste case study. Resour. Conserv. Recycl. 2020, 155, 104646. [CrossRef]

126. Gort, I.; Gerrits, A. Designing with Recycled Plastics: Case Guide. Available online: https:/ /www.partnersforinnovation.com/ wp-content/uploads/2020/05/Caseguide-Designing-with-Recycled-Plastics-digitaal-spreads.pdf (accessed on 6 July 2021).

127. Feil, A.; Pretz, T.; Jansen, M.; van Velzen, T.; Eggo, U. Separate collection of plastic waste, better than technical sorting from municipal solid waste? Waste Manag. Res. 2017, 35, 172-180. [CrossRef]

128. Groot, J.; Bing, X.; Bos-Brouwers, H.; Bloemhof-Ruwaard, J. A comprehensive waste collection cost model applied to postconsumer plastic packaging waste. Resour. Conserv. Recycl. 2014, 85, 79-87. [CrossRef]

129. Jacobsen, R.; Willeghems, G.; Gellynck, X.; Buysse, J. Increasing the quantity of separated post-consumer plastics for reducing combustible household waste: The case of rigid plastics in Flanders. Waste Manag. 2018, 78, 708-716. [CrossRef]

130. Tallentire, C.W.; Steubing, B. The environmental benefits of improving packaging waste collection in Europe. Waste Manag. 2020, 103, 426-436. [CrossRef]

131. Watkins, E.; Schweitzer, J.-P.; Leinala, E.; Börkey, P. Policy Approaches to Incentivise Sustainable Plastic Design. 2019. Available online: https:/ / www.oecd-ilibrary.org/environment/policy-approaches-to-incentivise-sustainable-plastic-design_233ac351-en (accessed on 6 May 2021).

132. Gesellschaft für Verpackungsmarktforschung mbH. Aufkommen und Verwertung von PET-Getränkeflaschen in Deutschland 2017: Endbericht. 2018. Available online: https://newsroom.kunststoffverpackungen.de/wp-content/uploads/2019/02/StudieVerwertung-PET-Getr\%C3\%A4nkeflaschen-2017-Kurzfassung.pdf (accessed on 16 July 2021).

133. Pivnenko, K.; Jakobsen, L.G.; Eriksen, M.K.; Damgaard, A.; Astrup, T.F. (Eds.) Challenges in plastics recycling. In Proceedings of the Sardinia 2015: Fifteenth International Waste Management and Landfill Symposium, Cagliari, Italy, 5-9 October 2015; CISA Publisher: Padova, Italy, 2015.

134. Hahladakis, J.N.; Iacovidou, E. An overview of the challenges and trade-offs in closing the loop of post-consumer plastic waste (PCPW): Focus on recycling. J. Hazard. Mater. 2019, 380, 120887. [CrossRef]

135. Brouwer, M.T.; van Velzen, T.; Eggo, U.; Ragaert, K.; ten Klooster, R. Technical Limits in Circularity for Plastic Packages. Sustainability 2020, 12, 10021. [CrossRef]

136. Bartsch, N. Polymer Additives, Contaminants and Non-Intentionally Added Substances in Consumer Products: Combined Migration, Permeation and Toxicity Analyses in Skin. Ph.D. Thesis, Freie Universität Berlin, Berlin, Germany, 2019.

137. Singh, P.; Saengerlaub, S.; Wani, A.A.; Langowski, H.-C. Role of plastics additives for food packaging. Pigment. Resin Technol. 2012, 41, 368-379. [CrossRef]

138. Thompson, R.C.; Moore, C.J.; Vom Saal, F.S.; Swan, S.H. Plastics, the environment and human health: Current consensus and future trends. Philos. Trans. R. Soc. Lond. B Biol. Sci. 2009, 364, 2153-2166. [CrossRef]

139. Andrady, A.L.; Neal, M.A. Applications and societal benefits of plastics. Philos. Trans. R. Soc. Lond. B Biol. Sci. 2009, 364, 1977-1984. [CrossRef]

140. Hernández-Alamilla, M.; Valadez-Gonzalez, A. The effect of two commercial melt strength enhancer additives on the thermal, rheological and morphological properties of polylactide. J. Polym. Eng. 2016, 36, 31-41. [CrossRef]

141. Selke, S.E.M.; Culter, J.D. Plastics Packaging: Properties, Processing, Applications, and Regulations; Carl Hanser Verlag GmbH Co KG: Munich, Germany, 2016; ISBN 3446437193. 
142. Hansen, E.; Nilsson, N.H.; Vium, K.S.R. Hazardous Substances in Plastics; Danish Ministry of the Environment, Environmental Protection Agency: Odense, Denmark, 2014; ISBN 8793283318.

143. European Chemicals Agency. Plastic Additives Initiative: Supplementary Information on Scope and Methods-15 February 2019. 2019. Available online: https:/ / echa.europa.eu/plastic-additives-initiative (accessed on 25 January 2020).

144. Koch, H.M.; Calafat, A.M. Human body burdens of chemicals used in plastic manufacture. Philos. Trans. R. Soc. Lond. B Biol. Sci. 2009, 364, 2063-2078. [CrossRef]

145. Arvanitoyannis, I.S.; Kotsanopoulos, K.V. Migration phenomenon in food packaging. Food-package interactions, mechanisms, types of migrants, testing and relative legislation-A review. Food Bioprocess Technol. 2014, 7, 21-36. [CrossRef]

146. World Health Organization. Antimony in Drinking-Water: Background Document for Development of WHO Guidelines for Drinking-Water Quality. 2003. Available online: https://www.who.int/water_sanitation_health/dwq/chemicals/antimony.pdf (accessed on 18 March 2020).

147. Filella, M. Antimony and PET bottles: Checking facts. Chemosphere 2020, 261, 127732. [CrossRef]

148. Teuten, E.L.; Saquing, J.M.; Knappe, D.R.U.; Barlaz, M.A.; Jonsson, S.; Björn, A.; Rowland, S.J.; Thompson, R.C.; Galloway, T.S.; Yamashita, R.; et al. Transport and release of chemicals from plastics to the environment and to wildlife. Philos. Trans. R. Soc. Lond. B Biol. Sci. 2009, 364, 2027-2045. [CrossRef]

149. Hermabessiere, L.; Dehaut, A.; Paul-Pont, I.; Lacroix, C.; Jezequel, R.; Soudant, P.; Duflos, G. Occurrence and effects of plastic additives on marine environments and organisms: A review. Chemosphere 2017, 182, 781-793. [CrossRef]

150. Oehlmann, J.; Schulte-Oehlmann, U.; Kloas, W.; Jagnytsch, O.; Lutz, I.; Kusk, K.O.; Wollenberger, L.; Santos, E.M.; Paull, G.C.; van Look, K.J.W. A critical analysis of the biological impacts of plasticizers on wildlife. Philos. Trans. R. Soc. Lond. B Biol. Sci. 2009, 364, 2047-2062. [CrossRef] [PubMed]

151. Business Wire. Global Polyvinyl Chloride (PVC) Market Size, Demand Forecasts, Industry Trends and Updates (2018-2025): ResearchAndMarkets.com. 2018. Available online: https://www.businesswire.com/news/home/20181024005331/en/GlobalPolyvinyl-Chloride-PVC-Market-Size-Demand (accessed on 3 August 2021).

152. Maqbool, F.; Mostafalou, S.; Bahadar, H.; Abdollahi, M. Review of endocrine disorders associated with environmental toxicants and possible involved mechanisms. Life Sci. 2016, 145, 265-273. [CrossRef]

153. Meeker, J.D.; Sathyanarayana, S.; Swan, S.H. Phthalates and other additives in plastics: Human exposure and associated health outcomes. Philos. Trans. R. Soc. Lond. B Biol. Sci. 2009, 364, 2097-2113. [CrossRef]

154. Filella, M.; Hennebert, P.; Okkenhaug, G.; Turner, A. Occurrence and fate of antimony in plastics. J. Hazard. Mater. 2019, 390, 121764. [CrossRef] [PubMed]

155. Chen, Y.; Awasthi, A.K.; Wei, F.; Tan, Q.; Li, J. Single-use plastics: Production, usage, disposal, and adverse impacts. Sci. Total Environ. 2021, 752, 141772. [CrossRef]

156. Babayemi, J.; Sindiku, O.; Osibanjo, O.; Weber, R. Substance flow analysis of polybrominated diphenyl ethers in plastic from EEE/WEEE in Nigeria in the frame of Stockholm Convention as a basis for policy advice. Environ. Sci. Pollut. Res. 2015, 22, 14502-14514. [CrossRef]

157. Jansson, K.D.; Zawodny, C.P.; Wampler, T.P. Determination of polymer additives using analytical pyrolysis. J. Anal. Appl. Pyrolysis 2007, 79, 353-361. [CrossRef]

158. Gu, F.; Guo, J.; Zhang, W.; Summers, P.A.; Hall, P. From waste plastics to industrial raw materials: A life cycle assessment of mechanical plastic recycling practice based on a real-world case study. Sci. Total Environ. 2017, 601, 1192-1207. [CrossRef] [PubMed]

159. Costal Plastic Recycling. Kunststoff-Kompendium: Überblick Über Gebräuchliche Kunststoffe, Ihre Verwendung, Ihre Kritischen Punkte und den Wahrheitsgehalt Häufig Anzutreffender Öffentlicher Kritik. Available online: www.coplare.net (accessed on 18 July 2021).

160. Groh, K.J.; Backhaus, T.; Carney-Almroth, B.; Geueke, B.; Inostroza, P.A.; Lennquist, A.; Leslie, H.A.; Maffini, M.; Slunge, D.; Trasande, L. Overview of known plastic packaging-associated chemicals and their hazards. Sci. Total Environ. 2019, 651, 3253-3268. [CrossRef]

161. Aliotta, L.; Vannozzi, A.; Panariello, L.; Gigante, V.; Coltelli, M.-B.; Lazzeri, A. Sustainable micro and nano additives for controlling the migration of a biobased plasticizer from PLA-based flexible films. Polymers 2020, 12, 1366. [CrossRef]

162. Danish Competent Authority for REACH. Annex XV Report: Proposal for a Restriction. Chromium (VI) Compounds. Available online: https:/ / echa.europa.eu/documents/10162/4d88d444-4b8b-48ab-9c11-6e74819e047c (accessed on 11 May 2021).

163. RIVM, The Netherlands. Annex XV Report-Identification of SVHC: Proposal for Identification of a Substance as a CMR cat 1 or 2, PBT, vPvB or a Substance of an Equivalent Level of Concern. Cobalt(II) Diacetate 200-755-8, The Netherlands. 2010. Available online: https:/ / echa.europa.eu/documents/10162/13640/svhc_axvrep_netherlands_cmr_co-diacetate_en.pdf (accessed on 11 May 2021).

164. ATSDR, Division of Toxicology and Human Health. Toxicological Profile for Lead. 2020. Available online: https://www.atsdr. cdc.gov / toxprofiles/tp13.pdf (accessed on 15 March 2020).

165. Bogaert, S.; Acoleyen, M.V.; Van Tomme, I.; Smet, L.D.; Fleet, D.; Salado, R. Study on RoHS and WEEE Directives N 30-CE0095296/00-09; ARCADIS \& RPA: Amsterdam, The Netherlands, 2008.

166. Fisk, P.R.; Girling, A.E.; Wildey, R.J. Prioritisation of Flame Retardants for Environmental Risk Assessment; Environment Agency: Wallingford, UK, 2003; ISBN 1844329569. 
167. Danish Environmental Protection Agency. Brominated Flame Retardants: Substance Flow Analysis and Assessment of Alternatives. Available online: https://www2.mst.dk/udgiv/Publications/1999/87-7909-416-3/html/kap01_eng.htm (accessed on 22 February 2020).

168. Janssen, S. Brominated Flame Retardants: Rising Levels of Concern; Health Care without Harm: Arlington, VA, USA, 2005.

169. United States Environmental Protection Agency. An Alternatives Assessment for the Flame Retardant Decabromodiphenyl Ether (DecaBDE): Final Report; United States Environmental Protection Agency: Washington, DC, USA, 2014.

170. Wassenaar, P.N.; Janssen, N.; de Poorter, L.R.; Bodar, C.W.M. Substances of Very High Concern and the Transition to a Circular Economy: An Initial Inventory; Rijksinstituut voor Volksgezondheid en Milieu RIVM: Bilthoven, The Netherlands, 2017. [CrossRef]

171. Morose, G. An Overview of Alternatives to Tetrabromobisphenol A (TBBPA) and Hexabromocyclododecane (HBCD). Lowell Center for Sustainable Production, University of Massachusetts, Lowell. 2006. Available online: http:/ / sustainableproduction. org/downloads / AternativestoTBBPAandHBCD.pdf (accessed on 3 August 2021).

172. Li, X.M.; Yang, R.J. Study on blooming of tetrabromobisphenol a bis (2, 3-dibromopropyl ether) in blends with polypropylene. J. Appl. Polym. Sci. 2006, 101, 20-24. [CrossRef]

173. Lassen, C.; Jensen, A.A.; Crookes, M.; Christensen, F.; Jeppesen, C.N.; Clausen, A.J.; Mikkelsen, S.H. Survey of brominated flame retardants. Regulation 2004, 52, 8 .

174. Dupont, D.; Arnout, S.; Jones, P.T.; Binnemans, K. Antimony recovery from end-of-life products and industrial process residues: A critical review. J. Sustain. Metall. 2016, 2, 79-103. [CrossRef]

175. European Communities. European Union Risk Assessment Report: Diantimony Trioxide; Rapporteur for the Risk Assessment of DIANTIMONY TRIOXIDE is the Swedish Chemicals Agency. 2008. Available online: https:/ / echa.europa.eu/documents/1016 2/553c71a9-5b5c-488b-9666-adc3af5cdf5f (accessed on 28 November 2021).

176. Lassen, P.; Hoffmann, L.; Thomsen, M. PAHs in Toys and Childcare Products; Environmental Protection Agency: Washington, DC, USA, 2012.

177. Federal Institute for Risk Assessment. Carcinogenic Polycyclic Aromatic Hydrocarbons (PAHs) in Consumer Products to be Regulated by the EU—Risk Assessment by BfR in the Context of a Restriction Proposal Under REACH: BfR Opinion Nr. $032 / 2010$. 26 July 2010. Available online: https:/ / mobil.bfr.bund.de/cm/349/carcinogenic_polycyclic_aromatic_hydrocarbons_pahs_in_ consumer_products_to_be_regulated_by_the_eu.pdf (accessed on 17 January 2020).

178. Fisner, M.; Taniguchi, S.; Majer, A.P.; Bícego, M.C.; Turra, A. Concentration and composition of polycyclic aromatic hydrocarbons (PAHs) in plastic pellets: Implications for small-scale diagnostic and environmental monitoring. Mar. Pollut. Bull. 2013, 76, 349-354. [CrossRef]

179. Shah, A.A.; Hasan, F.; Hameed, A.; Ahmed, S. Biological degradation of plastics: A comprehensive review. Biotechnol. Adv. 2008, 26, 246-265. [CrossRef] [PubMed]

180. Singh, B.; Sharma, N. Mechanistic implications of plastic degradation. Polym. Degrad. Stab. 2008, 93, 561-584. [CrossRef]

181. Cornelia Vasile, C.; Seymour, R.B. Handbook of Polyolefins—Synthesis and Properties; Marcel Dekker, Inc.: New York, NY, USA, 1993.

182. Manfredi, M.; Barberis, E.; Marengo, E. Prediction and classification of the degradation state of plastic materials used in modern and contemporary art. Appl. Phys. A 2017, 123, 35. [CrossRef]

183. Albertsson, A.-C. Long-Term Properties of Polyolefins; Springer Science \& Business Media: Berlin/Heidelberg, Germany, 2004; ISBN 3540407693.

184. Lucas, N.; Bienaime, C.; Belloy, C.; Queneudec, M.; Silvestre, F.; Nava-Saucedo, J.-E. Polymer biodegradation: Mechanisms and estimation techniques-A review. Chemosphere 2008, 73, 429-442. [CrossRef]

185. Arutchelvi, J.; Sudhakar, M.; Arkatkar, A.; Doble, M.; Bhaduri, S.; Uppara, P.V. Biodegradation of polyethylene and polypropylene. Indian J. Biotechnol. 2008, 7, 9-22.

186. Davison, N.L.; Barrère-de Groot, F.; Grijpma, D.W. Degradation of Biomaterials. In Tissue Engineering, 2nd ed.; van Blitterswijk, C.A., de Boer, J., Eds.; Academic Press: Amsterdam, The Netherlands, 2015; pp. 177-215, ISBN 9780124201453.

187. Mitchell, M.K.; Hirt, D.E. Degradation of PLA fibers at elevated temperature and humidity. Polym. Eng. Sci. 2015, 55, 1652-1660. [CrossRef]

188. Benítez, A.; Sánchez, J.J.; Arnal, M.L.; Müller, A.J.; Rodríguez, O.; Morales, G. Abiotic degradation of LDPE and LLDPE formulated with a pro-oxidant additive. Polym. Degrad. Stab. 2013, 98, 490-501. [CrossRef]

189. Ellen MacArthur Foundation. Holy-Grail. 2020. Available online: https://www.newplasticseconomy.org/assets/doc/HolyGrail.pdf (accessed on 20 June 2021).

190. EU Commission. Circular Plastics Alliance-Internal Market, Industry, Entrepreneurship and SMEs-European Commission. Available online: https:/ / ec.europa.eu/growth/industry/policy/circular-plastics-alliance_en (accessed on 15 May 2020).

191. European Commission. Commission Implementing Decision (EU) 2019/1004: Laying Down Rules for the Calculation, Verification and Reporting of Data on Waste in Accordance with Directive 2008/98/EC of the European Parliament and of the Council and Repealing Commission Implementing Decision C(2012) 2384. Notified under Document C(2019) 4114; European Commission: Brussels, Belgium, 2019.

192. Hessellink, T.; van Duuren, E. The Green Deal: A Game Changer for the Waste Management and Plastics Industries. 2021. Available online: https://assets.kpmg/content/dam/kpmg/nl/pdf/2021/sectoren/green-deal-plastic-recycling.pdf (accessed on 20 August 2021).

193. Moraga, G.; Huysveld, S.; De Meester, S.; Dewulf, J. Development of circularity indicators based on the in-use occupation of materials. J. Clean. Prod. 2021, 279, 123889. [CrossRef] 
194. Antonopoulos, I.; Faraca, G.; Tonini, D. Recycling of post-consumer plastic packaging waste in the EU: Recovery rates, material flows, and barriers. Waste Manag. 2021, 126, 694-705. [CrossRef]

195. Holdway, R.; Walker, D.; Hilton, M. Eco-design and successful packaging. Des. Manag. J. Former Ser. 2002, 13, 45-53. [CrossRef]

196. European Commission. Ecodesign Directive (Directive 2009/125/EC); European Commission: Brussels, Belgium, 2009.

197. Verschoor, B.A.; ten Klooster, R.; Korhonen, V.; Ylipoti, K.M. Integrating Key Figures and Consumer Benefits into a Packaging Development Method. In Proceedings of the 21st IAPRI World Conference on Packaging, Zhuhai, China, 19-22 June 2018; DEStech Publications, Inc.: Lancaster, PA, USA, 2018; ISBN 978-1-60595-046-4.

198. De Koeijer, B.; Borgman, I.; Henseler, J.; ten Klooster, R.; de Lange, J. Embedding a Sustainability Focus in Packaging Development Processes. In EcoDesign and Sustainability II; Kishita, Y., Matsumoto, M., Inoue, M., Fukushige, S., Eds.; Springer: Singapore, 2021; pp. 49-60, ISBN 978-981-15-6774-2.

199. Kaiser, K.; Schmid, M.; Schlummer, M. Recycling of Polymer-Based Multilayer Packaging: A Review. Recycling $2018,3,1$. [CrossRef]

200. Butler, T.I.; Morris, B.A. PE-Based Multilayer Film Structures. In Plastic Films in Food Packaging: Materials, Technology, and Applications; Ebnesajjad, S., Ed.; William Andrew: Waltham, MA, USA, 2013; pp. 21-52, ISBN 9781455731121.

201. Zhihong, C.; Hebin, Z.; Yanbo, W.; Binyan, L.; Yu, L. A vision-based robotic grasping system using deep learning for garbage sorting. In Proceedings of the 2017 36th Chinese Control Conference (CCC), Dalian, China, 26-28 July 2017; IEEE: New York, NY, USA, 2017; pp. 11223-11226, ISBN 978-988-15639-3-4.

202. Peršak, T.; Viltužnik, B.; Hernavs, J.; Klančnik, S. Vision-Based Sorting Systems for Transparent Plastic Granulate. Appl. Sci. 2020, 10, 4269. [CrossRef]

203. Sousa, J.; Rebelo, A.; Cardoso, J.S. Automation of Waste Sorting with Deep Learning. In Proceedings of the 2019 XV Workshop de Visão Computacional (WVC), São Bernardo do Campo, Brazil, 9-11 September 2019; IEEE: New York, NY, USA, 2019; pp. 43-48, ISBN 978-1-7281-5337-7.

204. Wilts, H.; Garcia, B.R.; Garlito, R.G.; Gómez, L.S.; Prieto, E.G. Artificial Intelligence in the Sorting of Municipal Waste as an Enabler of the Circular Economy. Resources 2021, 10, 28. [CrossRef]

205. Lukka, T.J.; Tossavainen, T.; Kujala, J.V.; Raiko, T. ZenRobotics Recycler-Robotic Sorting Using Machine Learning. Available online: https: / / citeseerx.ist.psu.edu/viewdoc/download?doi=10.1.1.465.94\&rep=rep1\&type=pdf (accessed on 5 July 2021).

206. Becker, W.; Sachsenheimer, K.; Klemenz, M. Detection of Black Plastics in the Middle Infrared Spectrum (MIR) Using Photon Up-Conversion Technique for Polymer Recycling Purposes. Polymers 2017, 9, 435. [CrossRef] [PubMed]

207. Wu, Y.; Pretz, T. (Eds.) Sensor based sorting: A key technology for sustainable waste management. In Proceedings of the EU Waste Managment 2010 Implementation of the Waste Framework Directive, Cologne, Germany, 8-9 June 2010.

208. Kulkarni, G.S. Introduction to Polymer and Their Recycling Techniques. In Recycling of Polyurethane Foams; Elsevier: Amsterdam, The Netherlands, 2018; pp. 1-16, ISBN 9780323511339.

209. Alvarado Chacon, F.; Brouwer, M.T.; van Thoden Velzen, E.U.; Smeding, I.W. A First Assessment of the Impact of Impurities in PP and PE Recycled Plastics; Wageningen University \& Research: Wageningen, The Netherlands, 2020.

210. Gundupalli, S.P.; Hait, S.; Thakur, A. A review on automated sorting of source-separated municipal solid waste for recycling. J. Waste Manag. 2017, 60, 56-74. [CrossRef]

211. Woidasky, J.; Moesslein, J.; Wendler, P.; Kirchenbauer, D.; Wacker, D.; Gao, G.; Lang-Koetz, C. Kunststoffidentifikation und -sortierung in der Circular Economy durch Fluoreszenzmarker. Chem. Ing. Tech. 2020, 92, 441-451. (In German) [CrossRef]

212. Gao, W.; Hundertmark, T.; Simons, T.J.; Wallach, J.; Witte, C. Plastics Recycling: Using an Economic-Feasibility Lens to Select the Next Moves. Available online: https:/ / www.mckinsey.com/industries/chemicals/our-insights/plastics-recycling-using-aneconomic-feasibility-lens-to-select-the-next-moves\# (accessed on 23 March 2021). 